\title{
Crustal structure of the basin and ridge system west of New Caledonia (Southwest Pacific) from wide-angle and reflection seismic data.
}

\author{
F. Klingelhoefer ${ }^{1, *}$, Y. Lafoy ${ }^{2}$, J. Collot ${ }^{1}$, E. Cosquer ${ }^{1}$, L. Géli ${ }^{1}$, H. Nouzé ${ }^{1}$, R. \\ Vially ${ }^{3}$
}

\author{
${ }^{1}$ Dep. of Geodynamics and Geophysics, IFREMER, Centre de Brest, B.P. 70, 29280 Plouzané, France. \\ ${ }^{2}$ Bureau of Geology and Mines, Department of Industry, Mines and Energy of New Caledonia, B.P. 465-98845, \\ Nouméa, New Caledonia \\ ${ }^{3}$ IFP, 1 \& 4, avenue de Bois-Preau 92852 Rueil-Malmaison Cedex, France \\ *: Corresponding author : F. Klingelhoefer, email address : $\underline{\text { fklingel@ifremer.fr }}$
}

\begin{abstract}
:
During the Zoneco 11 marine geophysical survey (September 2004), two deep reflection seismic profiles recorded by ocean bottom seismometers were acquired in the offshore domain west of New Caledonia. The northern profile crosses the New Caledonia Basin, the Fairway Ridge, the Fairway Basin, and the Lord Howe Rise. The southern profile crosses the Norfolk Rise south of New Caledonia, the New Caledonia Basin, the Fairway Ridge and Basin, and ends at the foot of Lord Howe Rise. On the northern profile the Lord Howe Rise has a crustal thickness of $23 \mathrm{~km}$ and exhibits seismic velocities and velocity gradients characteristic of continental crust. The crust thins to $12-15 \mathrm{~km}$ in the neighboring Fairway Basin, which is interpreted to be of thinned continental origin based on the seismic velocities. The crustal thickness of the Fairway Rise is $22 \mathrm{~km}$, and it is also interpreted to be of continental origin. The New Caledonian Basin is underlain by crust of $10 \mathrm{~km}$ thickness, which shows unusally high velocities (between 7.0 and 7.4) uncharacteristic for either thinned continental or oceanic crust. On the southern profile the Norfolk Rise is also found to be of continental nature. Here, the New Caledonia Basin shows velocities, crustal thickness, and basement roughness characteristic of typical oceanic crust. The crust in the Fairway Basin shows higher velocities than on the northern profile, which could be caused by volcanic intrusions into the crust during extension. A deep reflector in the upper mantle was imaged underneath the New Caledonian Basin on the northern profile.
\end{abstract}

Keywords: wide-angle seismic; SW Pacific; crustal structure. 


\section{Introduction and previous work}

${ }_{34}$ 2005a; Pelletier, 2006]. This opening was followed by a compressional phase in the late

${ }_{35}$ Eocene/early Oligocene at the end of which ophiolites were obducted onto New Caledonia

36

37

38

so quired crossing the Lord Howe Rise and the New Caledonia Basin [Shor et al., 1971].

${ }_{41}$ From modelling of the expanding-spread profiles acquired during the cruise, the authors

${ }_{42}$ concluded that the Lord Howe Rise is underlain by 18 to $25 \mathrm{~km}$ thick continental crust

${ }_{43}$ and the Norfolk Ridge by $21 \mathrm{~km}$ thick crust. Woodward and Hunt [1971] determined the

${ }_{44}$ crustal structure across the Tasman Sea from gravity measurements interpreted together

${ }_{45}$ with the first deep seismic results from Shor et al., [1971]. They confirmed the continental

${ }_{46}$ nature of Lord Howe Rise and proposed volcanic intrusions to explain short wavelength 
${ }_{47}$ gravity anomalies. They obtained a $9 \mathrm{~km}$ thick crust in the New Caledonia Basin from

48 gravity modelling.

49 During the Sonne SO-36 cruise, magnetic and gravimetric data were acquired on the

so Lord Howe Rise and Dampier Ridge and in the Lord Howe Basin [Schreckenberger et al.,

${ }_{51}$ 1992]. On the basis of modelling of magnetic data the authors concluded that continen-

52 tal crust with a highly magnetized lower crust and slightly less magnetized upper crust

${ }_{53}$ provides a better fit to the data than does a model with oceanic crust.

${ }_{54} \quad$ A major compressive phase during the upper Eocene and Middle Oligocene has been ${ }_{55}$ proposed from DSDP drilling and seismic profiling [Burns et al., 1973]. This lead to the

56 subaerial exposure of the Lord Howe Rise and created a regional erosional unconformity.

${ }_{57}$ This erosion is contemporaneous with the obduction of the ophiolite onto New Caledonia.

${ }_{58}$ A volcanic event associated with the post Oligocene subsidence of the area is identified

59 on the basis of imagery and seismic data [de Beuque et al., 1998; Exon et al., 2004]. The

60 authors confirmed the intermediate (continental intruded by volcanism) nature of the

61 Lord Howe Rise and proposed on the basis of the magnetic lineations, an oceanic origin

${ }_{62}$ of the Fairway Ridge and Basin.

${ }_{63}$ The Austradec $I$ and $I I$ marine seismic surveys were the first to discover the Fairway

${ }_{64}$ Ridge, a major structural feature which divides the New Caledonian (NC) basin into the

${ }_{65} \mathrm{NC}$ basin senso stricto and the Fairway Basin. they also found, that it plays an important

${ }_{66}$ role as a barrier in the distribution of sediments [Ravenne et al., 1977]. The Fairway ridge,

${ }_{67}$ previously interpreted as a ridge of oceanic nature [Ravenne et al., 1977; Mignot, 1984]

${ }_{68}$ and as an oceanic piece of the New Caledonia basin crust overthrust along the Lord How

69 Rise [Lafoy et al., 1994; de Beuque, 1999; Auzende et al., 2000] is now considered to 
zo be thinned continental crust [Vially et al., 2003; Lafoy et al., 2005b]. The origin of the

${ }_{71}$ Fairway Basin remains controversial to this day. Mignot [1984], Eade [1988], Uruski and

72 Wood [1991], van de Beuque [1999] and Auzende et al [2000] interpreted the substratum

${ }_{73}$ of Fairway Basin as oceanic in nature.

${ }_{74}$ The Moho depth underneath the south New Caledonia Basin has been found to be 75 slightly deeper than priviously thought from expanded spread profiles [Shor et al., 1971].

${ }_{76}$ The sub-seafloor basement depth of the New Caledonia Basin was found to increase to-

77 wards the west, from $2 \mathrm{~km}$ near Lord Howe Rise to $3 \mathrm{~km}$ near the Norfolk Ridge [Woodward 78 and Hunt, 1971]. Origin of the basin is controversial from oceanic type [Shor et al., 1971;

79 Dubois et al., 1974; Weissel and Hayes, 1977; Willcox et al., 1980; Kroenke, 1984; Mignot, so 1984; Sutherland, 1999; Auzende et al., 2000] to thinned continental type [Etheridge et al., ${ }_{81}$ 1989; Uruski and Wood, 1991; Sdrolias et al., 2003; Vially et al., 2003].

${ }_{82}$ The western margin of New Caledonia was previously interpreted as a subduction zone ${ }_{83}$ active before the late Eocene and the emplacement of the New Caledonia ophiolite [Dubois s4 et al., 1974; Kroenke, 1984; Collot et al., 1987]. In 1987 during the ZOE 400 cruise the ${ }_{85}$ margin was investigated by 14 seismic profiles [Rigolot and Pelletier, 1988]. The com${ }_{86}$ pressional sedimentary structures observed have been interpreted as representing a zone ${ }_{87}$ of deformation active between the Eocene compressional phase and the Upper Miocene ${ }_{88}$ or Piocene, and as having formed in response during the obduction of the peridotites on 89 New Caledonia, which never attained full subdcution [Rigolot and Pelletier, 1988].

so This would therefore also explain the absence of a fully developed volcanic arc on the 91 New Caledonia island [Rigolot and Pelletier, 1988]. The presence of a fully developed ${ }_{92}$ short-lived subduction zone west of New Caledonia could also be indicated by the presence 
${ }_{93}$ of some magmas related to an active margin found on the island [Cluzel et al., 2001; Collot

$94 \quad$ et al., 1987].

95 From modelling of the source-receiver functions of 15 large earthquakes from a land

96 station in Noumea Regnier [1988] constructed a simplified model of the crustal and mantle

${ }_{97}$ structure beneath southern New Caledonia. The final velocity-depth function shows a

98 Moho depth of $26+-1 \mathrm{~km}$. Two low velocity zones are observed in the mantle underneath

99 Noumea, the first between 40 and $50 \mathrm{~km}$ depth and the second from 60 to $65 \mathrm{~km}$ depth.

${ }_{100}$ The second low velocity zone dips towards the North. Due to the absence of a volcanic arc

\section{Data acquisition and quality}


115 parts, offering a dense coverage of $10 \mathrm{~nm}$ between instruments. All OBS except OBS 20,

${ }_{116}$ in which the hard disk failed, provided useful data. Four landstations where installed on

${ }_{117}$ the mainland by the IRD (Institut de Recherche pour le Developpement) in the extension

${ }_{118}$ of the profile, of which one gave useful data. A total of 3923 shots were fired on the profile

${ }_{119}$ by a $8530 \mathrm{in}^{3}$ airgun array tuned to single-bubble mode to enhance the low frequencies and ${ }_{120}$ allow deep penetration [Avedik et al., 1993]. The second deep seismic profile (Profile S) is

${ }_{121}$ located around $25^{\circ} \mathrm{S}$ (Figure 1) and has a length of $538 \mathrm{~km}$. It crosses the Norfolk Ridge, ${ }_{122}$ the New Caledonia Basin, the southern extension of the Fairway Ridge, the Fairway Basin ${ }_{123}$ and ends on the Lord Howe Rise. The profile was shot in two parts the first part using 15

${ }_{124}$ OBS and the second 12 OBS. All OBS provided useful data, except OBS50, which could 125 not be recovered. A total of 3922 shots were fired on this profile using the same airgun ${ }_{126}$ array as on Profile N. Multichannel seismic (MCS) data were acquired along the profiles ${ }_{127}$ using a $4.5 \mathrm{~km}$ long, 360 channel digital streamer.

${ }_{128}$ Processing of the multichannel seismic data was performed using the Geovecteur pro${ }_{129}$ cessing package. It included spherical divergence correction, FK-filtering, bandpass fil${ }_{130}$ tering (3-5-50-60 Hz), internal mute and dynamic corrections. Velocity analysis was per${ }_{131}$ formed every $200 \mathrm{CDP}$ for the final stack. The last processing step included applying ${ }_{132}$ an automatic gain control and a Kirchoff time migration. The sedimentary layers are ${ }_{133}$ well imaged in the reflection seismic section and the acoustic basement reflector is clearly ${ }_{134}$ distinguishable throughout the profiles. Clear reflections from the Moho are found in the 135 New Caledonia Basin and other regions.

On both profiles, additional gravimetric data were acquired using a BGM5 gravimeter, ${ }_{137}$ which offers a precision between 0.4 and $1.6 \mathrm{mGal}$ depending on the state of the sea, 

174 crustal thickness (Figure 7).

\section{Velocity modelling}


${ }_{224}$ Node spacing is the same as in Profile N: $1.5 \mathrm{~km}$ for the seafloor and sedimentary layers, 2255 and $10 \mathrm{~km}$ for the basement and crustal layers.

\section{Error analysis}




\section{Gravity modelling}


${ }_{273}$ for each layer of the seismic models were converted to densities using the relationship of

${ }_{274}$ Christensen and Mooney [1995] for crustal layers and that of Ludwig, Nafe and Drake

${ }_{275}[1970]$ for sedimentary layers. Upper mantle densities were set to a constant $3.32 \mathrm{~g} / \mathrm{cm}^{3}$.

${ }_{276}$ The lower crustal layer was divided into 3 regions on Profile N, of which the middle region ${ }_{277}$ underneath the New Caledonian Basin is characterized by slightly higher densities of 3.05

${ }_{278} \mathrm{~g} / \mathrm{cm}^{3}$ (Figure 13) as compared to $2.84 \mathrm{~g} / \mathrm{cm}^{3}$ along the rest of the profile. The density

279 of the lower crust on Profile $\mathrm{S}$ was divided into 5 regions of which the crust underneath

280 the Fairway Basin and New Caledonia Basin have higher densities around $2.91 \mathrm{~g} / \mathrm{cm}^{3}$ as

${ }_{281}$ compared to the densities underneath the rises (Figure 13) corresponding to the higher

${ }_{282}$ seismic velocities found in those the basins.

${ }_{283}$ The gravity data were forward modelled using the gravity module of the software of

${ }_{284}$ Zelt and Smith (1992). To avoid edge effects both models were extended by $100 \mathrm{~km}$ at

${ }_{285}$ both ends and down to a depth of $95 \mathrm{~km}$. The calculated anomalies can be compared with

${ }_{286}$ the shipboard measured gravity anomaly (Figure 13). The predicted anomalies generally

${ }^{287}$ fit the observed data well. The largest misfit on Profile $\mathrm{N}$ is observed at around 225

${ }_{288} \mathrm{~km}$ model distance and might be caused by three-dimensional effects of the basement

${ }_{289}$ topography. The largest misfits on Profile $\mathrm{S}$ are located on both profile ends where

290 the seismic constraints are weaker. An additional misfit around $450 \mathrm{~km}$ model offset is

${ }_{291}$ probably due to 3-D effects, as indicated by the positive gravity anomaly in the vicinity

${ }_{292}$ of the profile close to the location of OBS 36 (Figure 12).

\section{Comparison to reflection seismic data}

${ }_{293}$ The wide-angle seismic models converted to two-way travel-time show good agreement ${ }^{294}$ with the reflection seismic section (Figures $14(\mathrm{~A})$ and (B)). The most prominent sed- 
imentary reflectors were taken from Lafoy and Ship. Sci. Party [2004] with slight adjustments where necessary to fit the OBS data. However, only sedimentary reflectors discernible in the OBS data and therefore necessary for the modelling were included to avoid over-parametrization of the inversion. Velocities of these main sedimentary layers were constrained by wide-angle seismic data, but some additional layering is imaged by the reflection seismics. Depth of the acoustic basement is in very good agreement along the complete model.

On Profile N the first sedimentary layer incorporated into the velocity model corresponds to the sequence from Mid-Miocene to present (Figure $14(\mathrm{~A})$ ). The second layer comprises the Lower Miocene to post Upper Eocene sequences [Lafoy and Ship. Sci. Party, 2004]. The base of this layer is marked by a regional unconformity which was related to the obduction of the ophiolites onto New Caledonia and the corresponding compressional phase. The third sedimentary layer corresponds to the Cretaceous to Paleocene sequences. Lastly the fourth layer represents the acoustic basement. The reflection seismic data show two different facies, the first one diffractive and interpreted to be intrusive, and the second one reflective with possibly sedimentary structures. This facies could be interpreted as series from an ancient volcanic arc metamorphosed during the Rangitata orogeny in the Upper Jurassic or Lower Cretaceous [Lafoy and Ship. Sci. Party, 2004].

On Profile S only two instead of three sedimentary layers were included into the final velocity model (Figure 14 (B)). The first layer corresponds to the Miocene to present series and the second to the Cretaceous to Miocene series. In the New Caledonian Basin the acoustic basement shows a very diffractive facies and might correspond to the top of the oceanic crust. The Moho discontinuity, from wide-angle seismic data modelling 


\section{Results and discussion}


${ }_{343}$ basement highs in this region, which is found on both profiles (Figures 8 and 9) could

${ }_{344}$ be explained by continental crust with a considerable magnetization in the lower crust

${ }_{345}$ [Schreckenberger et al., 1992].

${ }_{346}$ In the basins of Profile $\mathrm{N}$ the sedimentary layer thickness increases to up to $5 \mathrm{~km}$ in the ${ }_{347}$ eastern part of the asymmetric New Caledonia Basin and $4 \mathrm{~km}$ in the more symmetric ${ }_{348}$ Fairway Basin. Sedimentary thickness is lower on Profile S, with up to $3 \mathrm{~km}$ in both basins. 349 The crustal thickness decreases on Profile N to $8 \mathrm{~km}$ in New Caledonia Basin and to $10 \mathrm{~km}$ 350 in the Fairway Basin. The Fairway Basin crust on Profile N is thicker than normal oceanic ${ }_{351}$ crust. The seismic velocities and the relative thickness of the crustal layers are identical ${ }_{352}$ to the Lord Howe Rise and Fairway Ridge. This indicates that the Fairway Basin results ${ }_{353}$ from thinning of continental crust during extension. On Profile $\mathrm{S}$ the crustal thickness ${ }_{354}$ of the Fairway Basin is around 12 to $15 \mathrm{~km}$ and the lower crust exhibits elevated lower 355 crustal velocities as compared to the bordering Lord Howe Rise and Fairway Ridge. As in ${ }_{356}$ the north the crustal and the relative layer thicknesses correspond to thinned continental ${ }_{357}$ rather than oceanic crust. A possible explanation for the elevated lower crustal velocities ${ }_{358}$ and densities could be intrusions into the lower crust emplaced during the rifting of the 359 basin.

360

Comparison of crustal velocity-depth profiles from the New Caledonia Basin on Profile ${ }_{361} \mathrm{~N}$ and Profile S to typical oceanic crust [White et al., 1992] indicates that, although ${ }_{362}$ crustal thickness on both profiles is only slightly thicker than for oceanic crust, the seismic
June 16, 2007, 1:41pm 
On Profile S the velocity-depth profile from the New Caledonia Basin is indicative of normal oceanic crust. The slightly elevated crustal densities in the New Caledonia Basin can by explained by the presence of oceanic crust. Also, the basement character in the basin changes from the northern Profile N, where it is characterised by large blocks, to the southern profile where it shows a roughness characteristic for oceanic crust, with highs 15$20 \mathrm{~km}$ spaced about apart (Figure 17 (a) and (b)). In the middle of the basin a pronounced basement high correlates with a $200 \mathrm{nT}$ magnetic signature, which might correspond to an extinct spreading centre (Figure $17(\mathrm{~b})$ ). The modelling of the magnetic anomalies in New Caledonian Basin indicates a crust of basaltic origin which is clearly correlated with the topography of the basin and the absence of magnetic anomalies [Collot, 2005]. The absence of magnetic anomalies in the basin can be explained by the fact that the basin is too narrow to span several magnetic reversals or that the crust was constructed during the Cretaceous quiet time [Collot, 2005].

Neighbouring segments along the spreading axis in back-arc basins can display highly contrasted axial morphologies as found in the North Fiji Basin [Garel et al., 2003]. Bathymetric studies of the Fiji back-arc basin demonstrate that both axial highs typical of fast spreading, and valleys typical of slow and very slow spreading, can be found along a single segment. This fact can be explained by spatial variations in the distribution of upper mantle convection cells below accretion centers superimposed on the thermal anomaly located under the whole basin [Garel et al., 2003]. We propose that theNew Caledonia Basin crust on Profile $\mathrm{S}$ is generated by a magmatically spreading segment, and therefore shows features typical for normal oceanic crust: a division into one two seismically distinguishable layers (the basaltic and the gabbroic layer), a basement roughness typical 

${ }_{427}$ However, the westward deepening of the reflector does not fit to a proposed eastward dip

428

429

for oceanic crust, and an axial high corresponding to the spreading center. The much stronger Moho reflection (Figure 15) here originates from the base of the gabbroic layer.

Modelling of the wide-angle seimic data resulted in imaging for the first time a strong reflector in the upper mantle of the New Caledonia Basin (Figure 8). Documentation of mantle structures can help improve our understanding of how the subcrustal lithosphere is deformed and the relative behaviour between the crust and the upper mantle. The most widely studied mantle reflector is the Flannan reflector beneath the Devonian-Triassic West Orkney Basin off Scotland [McBride et al., 1995], which has been imaged to a depth of about $80 \mathrm{~km}$. Among the proposed mechanisms for the origin of this reflector are the Caledonian orogeny [Brewer and Smythe, 1984] as well as the subsequent basin extension [Reston, 1993; Stein and Blundell, 1990]. A later study proposed either differential extension of crust at least partially coupled to the uppermost mantle, or a broad zone of simple shear that was largely confined to the upper mantle but reactivated to deform the crust, as the origin for the Flannan mantle reflector [McBride et al., 1995].

The top of one of the two low velocity zones underneath New Caledonia proposed from modelling of the source-receiver functions [Regnier, 1988] may correspond to the mantle reflector found in this study. In this case, the mantle reflector would represent to the top of a subducted plate from an earlier eastward subduction underneath New Caledonia. of the low velocity zone. A strong mantle reflector at about $35 \mathrm{~km}$ depth has also been imaged beneath a $40 \mathrm{~km}$-wide, back-arc extension zone on North Island, New Zealand, a geologic setting which may be similar to that of the New Caledonia Basin. The authors propose the origin of this reflector to be the top of a reservoir of partial melt [Stratford 
${ }_{432}$ and Stern, 2004]. As no excessive volcanism has been found in the New Caledonia Basin

${ }_{433}$ this hypothesis seems unlikely for the New Caledonia Basin.

${ }^{434}$ Although the landstation data do not allow to trace the mantle reflector in the vicinity

${ }_{435}$ of New Caledonia it general inclination suggests, that it gets in contact with the Moho

${ }_{436}$ underneath New Caledonia. Therefore, the most likely explanation of the origin of the

${ }_{437}$ mantle reflector is that it formed during the extensional phase of the New Caledonian

${ }_{438}$ basin and represents a shear zone in the mantle. No deep reflection has been modelled

439 on Profile S, which might either be caused by the data quality or by the fact, that the

${ }_{440}$ reflector is confined to the middle segment of the New Caledonian Basin.

\section{Conclusions}

${ }_{441}$ Modelling of the wide-angle seismic data from the ZONECO 11 cruise confirmed of ${ }_{442}$ the continental nature of the Lord Howe Ridge, and enabled the determination of nature ${ }_{443}$ of the crust of the Fairway Ridge and the Norfolk Rise, which are also shown to be

${ }_{444}$ continental. This strengthens the hypothesis that all three ridges formed by fragmentation

${ }_{445}$ of Gondwanaland, caused either by widespread extension or in a backarc setting.

${ }_{446}$ The Fairway Basin shows relative layer thicknesses and upper crustal velocity gradients

${ }_{447}$ typical for thinned continental crust. Its lower crustal velocities indicate a continental

${ }_{448}$ origin on Profile N. Velocities are slightly elevated on the southern profile, which can be

${ }_{449}$ explained by intrusions into the lower crust. This would also explain the slightly higher

450 density found from gravity modelling.

${ }_{451}$ The crust in the New Caledonia Basin on Profile N was modelled using velocities which

${ }^{452}$ are higher than either typical oceanic or continental crust. We propose that the crust

${ }_{453}$ in this region consists to a high degree of serpentinised upper mantle material generated 
${ }_{454}$ during an amagmatic phase of opening of the basin, as has been found on ultra-slow

${ }_{455}$ spreading centres. This implies the absence of oceanic magnetic anomalies and of an

${ }_{456}$ axial high, which would be consistent with magmatic spreading. On Profile $\mathrm{S}$ the basin

${ }_{457}$ shows typical oceanic seismic velocities and relative layer thicknesses. Its basement is also

${ }_{458}$ characterised by typical oceanic roughness. We therefore propose that extension in this

${ }_{459}$ area resulted in magmatic sea-floor spreading.

460

A mantle reflector dipping towards the west has been identified beneath the New Caledo-

461 nian Basin. Its dip does not correspond to the top of a low velocity zone found underneath

${ }_{462}$ New Caledonia from receiver function analysis, which has been associated to an eastward ${ }_{463}$ subduction underneath the island [Regnier, 1988]. The absence of large amounts of vol-

${ }^{464}$ canism seems to exclude its origin as the head of a melt-bearing zone as proposed for a

${ }_{465}$ similar reflector on the North island of New Zealand [Stratford and Stern, 2004]. One

${ }_{466}$ explanation could be that it probably originates from the extensional tectonics during

${ }_{467}$ opening of the New Caledonian Basin.

\section{${ }_{468}$ Acknowledgments.}

${ }_{469}$ We would like to thank the captain and the crew of the $\mathrm{N} / \mathrm{O}$ Atalante. Acquisition 470 and processing of the data was funded by the ZoNéCo program of the ADECAL (Agence ${ }_{471}$ de Développement Economique de la Nouvelle Calédonie) in cooperation with Ifremer ${ }_{472}$ (Institute Français de Recherche pour l'Exploitation de la mer) and the IFP (Institut ${ }_{473}$ Français du Pétrole). The GMT [Wessel and Smith, 1995] and Seismic Unix software ${ }_{474}$ package [Stockwell, 1999] were used in the preparation of this paper. We would like to ${ }_{475}$ thank B. Pontoise (IRD) for deploying the landstations and A. Nercessian and S. Rouzo 
${ }_{476}$ for help in the data acquisition. We thank M.-A. Gutscher for help with the English.

${ }_{477}$ Many thanks also to B. Pelletier and N. F. Exon for reviews which helped improve the

${ }_{478}$ manuscript.

\section{References}

${ }_{479}$ Abers, G. A., P. E. van Keken, E. A. Kneller, A. Ferris, and J. C. Stachnik, The thermal ${ }_{480}$ structure of subduction zones constrained by seismic imaging: Implications for slab

481

482

483

484

491 dehydration and wedge flow, Earth Planet. Sci. Lett., 241, pp. 387-397, 2006.

Aitchison, J., G. Clarke, S. Meffre, and D. Cluzel, Eocene arc-continent collision in New Caledonia and implications for regional southwest Pacific tectonic evolution., Geology, 23, 2, pp. 161-164, 1995.

Auzende, J. M., S. van den Beuque, M. Regnier, Y. Lafoy, and P. A. Symonds, Origin of New Caledonian Ophiolite based on a French-Australian Transit (faust), Mar. Geol., 162(2-4), pp. 225-236, 2000.

Avedik, F., V. Renard, J. Allenou, and B. Morvan, "Single bubble" air-gun array for deep exploration, Geophysics, 58, pp. 366-382, 1993.

Avias, J., Overthrust structure of the main ultrabasic New Caledonian massifs, Tectonophysics 4(4-6), pp. 531-541, 1967.

Brewer, J. A., and D. K. Smythe, MOIST and the continuity of crustal reflector geometry along the Caledonian-Appalachian orogen, J. Geol. Soc. London, 141, pp. 105-120, 1984.

Burns, R. E., J. E. Andrews, and the scientific party, Site 208, Initial Reports of the Deep Sea Drilling Project, pp. 271-331, 1973. 
Caress, D., M. McNutt, R. Detrick, and J. Mutter, Seismic imaging of hotspot-related crustal underplating beneath the Marquesas Islands, Nature 373, pp. 600-603, 1995.

Carlson, R. L., N. I. Christensen, and R. P. Moore, Anomalous crustal structures in ocean basins: Continental fragments and oceanic plateaus, Earth Planet. Sci. Lett., 51, pp. $171-180,1980$.

Charvis, P., M. A. Laesanpura, J. Gallart, A. Hirn, J.-C. Lépine, B. de Voogd, T. Minshull, Y. Hello, and B. Pontoise, Spatial distribution of hotspot material added into the lithosphere under la réunion, J. Geophys. Res. 104, pp. 2875-2893, 1999.

Christensen, N. I., and W. D. Mooney, Seismic velocity structure and composition of the continental crust; a global view, J. Geophys. Res., 100, 6, pp. 9761-9788, 1995.

Cluzel, D., J. C. Aitchison, and C. Picard, Tectonic accretion and underplating of mafic terranes in the Late Eocene intraoceanic fore-arc of New Caledonia (Southwest Pacific)): geodynamic implications, Tectonophysics, 340, pp. 23-59, 2001.

Coakley, B. J., and J. R. Cochran, Gravity evidence of very thin crust at the Gakkel Ridge (Arctic Ocean), Earth Planet. Sci. Lett., 163, pp. 81-95, 1998.

Cohen, J. K., and J. W. Stockwell, Seismic Unix Release 37: a free package for seismic research and processing, Center for Wave Phenomena, Colorado School of Mines., 2003.

Collot, J., Amorce de synthèse des connaissances des bassins du sud ouest pacifique et hypothèses sur l'origine et la nature du bassin de nouvelle calédonie dans sa partie centrale : apport des données de la campagne zoneco-11., Masters Thesis, p. 61, 2005.

Collot, J.-Y., A. Malahoff, J. Recy, G. Latham, and F. Missegue, Overthrust emplacement of the New Caledonia Ophiolite: Geophysical evidence, Tectonics, 6, 3, pp. 215-232, 1987. 
Crawford, A. J., S. Meffre, and P. A. Symonds, 120 to 0 ma tectonic evolution of the southwest pacific and analogous geological evolution of the 600 to 220 ma tasman fold belt system., Geol. Soc. Australia Spc. Publ., 22, pp. 377-397, 2003.

de Beuque, S. V., Evolution geologique du domaine peri-caledonien (Sud Ouest Pacifique), Ph. D. Thesis, University of Brest, p. 270pp, 1999.

de Beuque, S. V., J.-M. Auzende, Y. Lafoy, and F. Missegue, Tectonique et volcanisme tertiare sur a ride de lord howe (Sud-Ouest Pacifique, C. R. Acad. Sci. Paris, pp. 663669, 1998.

Den, N., W. J. Ludwig, S. Murauchi, J. I. Ewing, H. Hotta, N. T. Edgar, T. Yoshii, T. Asanuma, K. Hagiwara, T. Sato, and S. Ando, Seismic-refraction measurements in the northwest Pacific basin, J. Geophys. Res., 75, p. 1421, 1969.

Dubois, J., J. Launay, and J. Recy, Uplift movements in New Caledonia-Loyalty Islands area and their plate tectonics interpretation, Tectonophysics, 24, pp. 133-150, 1974.

Eade, J. V., The Norfolk Ridge system and its margins, In: The ocean basins and margins, Plenum. New York, United States, pp. 303-324, 1988.

Etheridge, M. A., P. A. Symonds, and G. S. Lister, Application of the detachment model to reconstruction of conjugate passive margins, AAPG Bull 46, p. 23?40, 1989.

Exon, N., P. Hill, Y. Lafoy, M. Fellows, K. Perry, P. Mitts, R. R. Howe, G. Chaproniere, G. Dickens, B. Ussler, and C. Paull, Geology of the Fairway and New Caledonia Basins in the Tasman Sea from: sediment, pore water, diapirs and bottom simulating reflectors (Franklin Cruise FR9/ 01 and Geoscience Australia Survey 232), Geoscience Australia Record 2004/26, pp. 291-300, 2004. 
${ }_{542}$ Exon, N. F., Y. Lafoy, P. J. Hill, G. R. Dickens, and I. Pecher, Geology and petroleum

${ }_{543}$ potential of the Fairway Basin in the Tasman sea, Australian J. Earth Sci., pp. 629-645,

2007.

${ }_{545}$ Francis, T. J. G., and R. W. Raitt, Seismic refraction measurements in the southern

546 Indian Ocean, J. Geophys. Res., 72, p. 3015, 1967.

${ }_{547}$ Francis, T. J. G., D. Davies, and M. N. Hill, Crustal structure between kenya and the ${ }_{548} \quad$ seychelles, Philos. Trans. R. Soc. London, Ser. A, 259, p. 240, 1966.

${ }_{549}$ Gaina, C., D. R. Muller, J. Y. Royer, J. Stock, J. Hardebeck, and P. Symonds, The ${ }_{550}$ tectonic history of the Tasman Sea: A puzzle with 13 pieces, Earth Planet. Sci. Lett., ${ }_{551} \quad 197,3-4$, pp. 273-286, 1998.

${ }_{552}$ Garel, E., Y. Lagabrielle, and B. Pelletier, Abrupt axial variations along slow to ultra${ }_{553}$ slow spreading centers of the northern north Fidji Basin (sw pacific): Evidence for short

554 
579

Kroenke, L. W., Cenozoic tectonic development of the Southwest Pacific, Committee for co-ordination of joint prospecting for mineral resources in South Pacific offshore areas (CCOP/SOPAC) Tech. Bull., New Zealand, p. 122pp, 1984.

Lafoy, Y., and Ship. Sci. Party, Rapport de mission de la campagne zonéco 11 de sismique lourde (multitraces, réfraction, haute résolution) à bord du N/O L'Atalante (8 sept.-5 oct. 2004), p. 147, 2004.

Lafoy, Y., B. Pelletier, J. M. Auzende, F. Missegue, and L. Molard, Tectonique compressive Cénozoique sur les rides de Fairway et de Lord Howe, entre Nouvelle Calédonie et Australie, C. R. Acad. Sci. Paris, 319, pp. 1063-1069, 1994.

Lafoy, Y., I. Brodien, R. Vially, and N. F. Exon, Structure of the basin and ridge system west of New Caledonia (Southwest Pacific): A synthesis, Mar. Geophys. Res., 26, pp. 37-50, 2005a.

Lafoy, Y., L. Géli, F. Klingelhoefer, R. Vially, B. Sichler, and H. Nouzé, Discovery of continental stretching and oceanic spreading in the Tasman Sea, EOS, 10, pp. 101-108, 2005b.

Ludwig, J. W., J. E. Nafe, and C. L. Drake, Seismic refraction, The Sea, 4, 1, pp. 53-84, 1970.

McBride, H. H., D. B. Snyder, M. P. Tate, R. W. England, and R. W. Hobbs, Upper mantle reflector structure and origin beneath the Scottish Caledonides, Tectonics, 14 (5), pp. 1351-1367, 1995.

Michael, P. J., G. H. Langmuir, H. J. B. Dick, J. E. Snow, S. L. Goldstein, K. Lehnert, G. Kurras, W. Jokat, R. Muehe, and H. N. Edmonds, Magmatic and amagmatic seafloor generation at the ultraslow-spreading Gakkel ridge, Arctic Ocean, Nature, 423, pp. 956- 
961, 2003.

Mignot, A., Sismo-stratigraphie de la terminaison nord de la ride de lord howe, evolution geodynamique du sud-ouest pacifique entre l'australie et la nouvelle- caledonie, $P h . D$. Thesis, Universite Pierre et Marie Curie, p. 203pp, 1984.

Ohara, Y., Mantle process beneath Philippine Sea back-arc spreading ridges: A synthesis of peridotite petrology and tectonics, Island Arc, 15, pp. 119-129, 2006.

Ohara, Y., R. J. Stern, T. Ishii, H. Yurimoto, and T. Yamazaki, Peridotites from the Mariana Trough: first look at the mantle beneath an active back-arc basin, Contrib. Mineral. Petrol., 143, pp. 1-18, 2002.

Paris, J. P., Sur l'âge éocène supérieur de la mise en place de la nappe ophiolithique de Nouvelle Calédonie déduit d'observations nouvelles sur la série de Népoui, $C . R$. Acad. Sci. Paris, série D, pp. 1659-1661, 1979.

Pelletier, B., Geology of the New Caledonia region and its implications for the study of the New Caledonian biodiversity, In: Compendium of marine species from New Caledonia, C. Payri and B. Richer de Forges (Eds), forum Biodiversite des Ecosystemes Coralliens, Doc. Sci. Tech. IRD, pp. 17-30, 2006.

Ravenne, C., C. E. de Broin, J. Dupont, A. Lapouille, and J. Launay, New Caledonia basin-Fairway Ridge: structural and sedimentary study, In: Editions TECHNIP, International Symposium on Geodynamics in the South-West Pacific Nouméa, 1976, pp. $145-154,1977$.

Regnier, M., Lateral variation of upper mantle structure beneath New Caledonia determined from P-wave receiver function: evidence for a fossil subduction zone, Geophys. J., pp. 561-577, 1988. 
${ }_{611}$ Reston, T. J., Evidence for extensional shear zones in the mantle, offshore Britain, and ${ }_{612}$ their implication for the extension of the continental lithosphere, Tectonics, pp. 492-506, $613 \quad 1993$

${ }_{614}$ Rigolot, P., and B. Pelletier, Tectonique compressive récente le long de la marge Ouest ${ }_{615}$ de la Nouvelle-Caledonie : Résultats de la campagne ZOE 400 du N/O Vauban (mars ${ }_{616}$ 1987), C. R. Acad. Sci. Paris, 307 (II), pp. 179-184, 1988.

${ }_{617}$ Sandwell, D., and W. Smith, Marine gravity from satellite altimetry, The Geological Data ${ }_{618}$ Center, Scripps Institution of Oceanography, La Jolla, CA92093 (digital file, version

\section{2), (anonymous ftp to baltica.ucsd.edu), 1995.}

Schreckenberger, B., H. A. Roeser, and P. A. Symonds, Marine magnetic anomalies over the Lord Howe Rise and the Tasman sea: Implications for the magnetization of the lower continental crust, Tectonophysics, 212, pp. 77-97, 1992.

Sdrolias, M., D. R. Mueller, and C. Gaina, Tectonic evolution of the southwest pacific using constraints from backarc basins, In: Evolution and dynamics of the Australian Plate, R. R. Hills and D. R. Mueller (eds), Geol. Soc. of America Spec. Pap. 372, pp. $343-359,2003$.

Shor, G. G., H. K. Kirk, and H. W. Menard, Crustal structure of the Melanesian area, J. Geophys. Res., pp. 2562-2586, 1971.

Smith, W., and D. Sandwell, Global seafloor topography from satellite altimetry and ship depth soundings, Science 27r, pp. 1956-1962, 1997.

Stein, A. M., and D. J. Blundell, Geological inheritance and crustal dynamics of the northwest Scottish continental shelf, Tectonophys., pp. 455-467, 1990.

Stockwell, J. W., The cwp/su: Seismic un*x package, Computers and Geosciences, 1999. 
${ }_{634}$ Stratford, W. R., and T. A. Stern, Strong seismic reflections and melts in the mantle of a continental back-arc basin, Geophys. Res. Lett., 31, 2004.

636

637

638

639

640

641

642

643

644

645

646

647 64891.

649

650

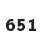

652

653

654

655

656 1999. 1996. 1985.

Sutherland, R., Basement geology and tectonic development of the greater New Zealand region: an interpretation from regional magnetic data, Tectonophys. 308, pp. 341-362,

Sutton, G. H., G. L. Maynard, and D. M. Hussong, Widespread occurrence of a highvelocity basal layer in the Pacific crust found with repetitive sources and sonobuoys, in: The structure and physical properties of the earth's crust, ed. J. G. Heacock, Am. Geophys. Union, p. 193, 1971.

Symonds, P. A., J. B. Colwell, H. I. M. Struckmeyer, J. B. Willcox, and P. J. Hill, Mesozoic rift basin developement off eastern australia, Geol. Soc. Aust. Abstr. 43, pp. 528-542,

Uruski, C., and R. Wood, A new look at the new caledonia basin, an extension of the taranaki basin, offshore north island, new zealand, Mar. Pet. Geol., 8, pp. 379-391,

Vially, R., Y. Lafoy, J. M. Auzende, and R. France, Petroleum potential of New Caledonia and its offshore basins, AAPG int. Conf., Barcelona, Spain, pp. 1-6, 2003.

Watts, A., U. ten Brink, P. Buhl, and T. Brocher, A multichannel seismic study of lithospheric flexure across the hawaiian -emperor seamount chain, Nature 315, pp. 105-111,

Watts, A. B., C. Peirce, J. Colier, R. Dalwood, J. P. Canales, and T. J. Henstock, A seismic study of lithospheric flexure in the vicinity of Tenerife, Canary Islands, Earth Planet. Sci. Lett. 146, pp. 431-447, 1997. 


\section{Figure Captions}


${ }_{679}$ physiographic features are annotated. (B) Location map of the wide-angle seismic profiles

(Box in A). Circles show OBS locations and inverted triangles IRD landstations. Contours are predicted seafloor bathymetry from satellite gravity [Smith and Sandwell, 1997] in an $1000 \mathrm{~m}$ interval.

Figure 2: (a) Bandpass filtered $(3-5 \mathrm{~Hz}, 24-36 \mathrm{~Hz})$ vertical geophone data section from OBS 04 located in the New Caledonia Basin on Profile N. The data are displayed with a gain proportional to source-receiver offset and are reduced at a velocity of $6 \mathrm{~km} / \mathrm{s}$. PmP (reflection from the Moho), Pm2P (reflection from the deep mantle reflector) and Pn (turning waves fromt he upper mantle) are annotated (b) Synthetic seismograms calculated from the velocity model for the same station using the finite-difference modelling code from the Seismic Unix package [Cohen and Stockwell, 2003; Stockwell, 1999]. The synthetic seismograms are calculated every $100 \mathrm{~m}$ with a source frequency centred around $5 \mathrm{~Hz}$. The deep mantle reflection is not reproduced because no velocity increase is associated to the reflector.

Figure 3: (a) Data from the vertical geophone data section from OBS 13 located on the Fairway Ridge on Profile N. The same gain, filter and scaling have been applied as in Figure 2 a. (b) Corresponding synthetic seismograms calculated from the model using the same method as in Figure $2 \mathrm{~b}$.

Figure 4: (a) Data from the vertical geophone data section from OBS 16 located in the Fairway Basin on Profile N. The same gain, filter and scaling have been applied as in Figure 2 a. (b) Corresponding synthetic seismograms calculated from the model using the same method as in Figure $2 \mathrm{~b}$. 
${ }_{717}$ Profile N. 
${ }_{724}$ calculated travel times (line) of the sedimentary layers for all receivers along the Profile ${ }_{725}$ N. (B) Same as (A) but for the crustal layers (C) Same as (A) but for the Moho and ${ }_{726}$ upper mantle layers. (D) Same as (A) but for Profile S (E) Same as (D) but for crustal ${ }_{727}$ layers (E) Same as (D) but for the Moho and upper mantle layers.

744 in

Resolution parameter for all depth nodes of the velocity model of Profile S. OBS positions are marked by black circles. Contour interval is 0.1 . The depth uncertainty of the most important boundaries calculated from the $95 \%$ confidence limit of the f-test is given in the framed boxes.

Figure 12: Free air gravity anomaly in the study area from satellite altimetry [Sandwell and Smith, 1995], contoured every $10 \mathrm{mGal}$. The gravity anomaly north of Profile S causes a discrepancy between measured gravity by satellite and predicted gravity anomaly from modelling (marked by arrow).

Figure 13: (A) Upper panel: Shipboard measured free-air gravity anomaly (black line) and predicted anomaly from modelling (dashed line) along Profile N. Lower panel: Gravity model of Profile N. Positions of OBSs (circles) and landstations (inverted triangles) are indicated. Italic numbers give densities used for gravity modelling in $\mathrm{g} / \mathrm{cm}^{3}$. Black line indicate layer boundaries from seismic modelling and dashed lines additional boundaries for gravity modelling. (B) Upper panel: Shipboard measured free-air gravity anomaly (black line) and predicted anomaly from modelling (dashed line) along Profile S. Lower 
${ }_{747}$ panel: Gravity model of Profile S. Positions of OBSs (circles) are indicated. Italic numbers

748 give densities used for gravity modelling in $\mathrm{g} / \mathrm{cm}^{3}$. Black line indicate layer boundaries

749 from seismic modelling and dashed black lines addition boundaries for gravity modelling.

Figure 14: (A) Migrated multichannel seismic section of Profile N. OBS positions are ${ }_{751}$ indicated by black circles and layer boundaries from wide-angle data modelling by black

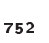

753

754 
769 Figure 17: Comparison of reflection seismic sections from the New Caledonia Basin along

770 Profile N (A) and Profile S (B).

${ }_{771}$ Figure 18: Blow-up reflection seismic section of the sedimentary layers in the New ${ }_{772}$ Caledonia Basin on Profile N and the parallel reflection seismic Profile Z11-02 about 25 ${ }_{773} \mathrm{~km}$ to the north (see Figure 1 for location). 
Phase No of picks RMS traveltime residual chi-squared

\begin{tabular}{|c|c|c|c|c|}
\hline Water & 1 & 4440 & 0.029 & 0.086 \\
\hline Sediments 1 & 2 & 19 & 0.025 & 0.068 \\
\hline Sediments 1 reflection & 4 & 1029 & 0.079 & 0.619 \\
\hline Sediments 2 & 3 & 609 & 0.096 & 0.927 \\
\hline Sediments 2 reflection & 5 & 899 & 0.088 & 0.782 \\
\hline Sediments 3 & 9 & 271 & 0.062 & 0.391 \\
\hline Basement reflection & 17 & 224 & 0.146 & 2.136 \\
\hline Upper crust & 14 & 7528 & 0.134 & 1.778 \\
\hline lower crust & 11 & 4703 & 0.157 & 2.473 \\
\hline $\mathrm{PmP}$ & 7 & 4342 & 0.182 & 3.293 \\
\hline Pn & 8 & 346 & 0.149 & 2.227 \\
\hline Mantle reflection & 13 & 355 & 0.772 & 59.695 \\
\hline
\end{tabular}

D R A F T

June 16, 2007, 1:41pm

D R A F T
All Phases
27005
0.159
2.529

Table 1. Traveltime residuals and chi-squared error for all phases and the complete model of Profile N. 
Phase No of picks RMS traveltime residual chi-squared

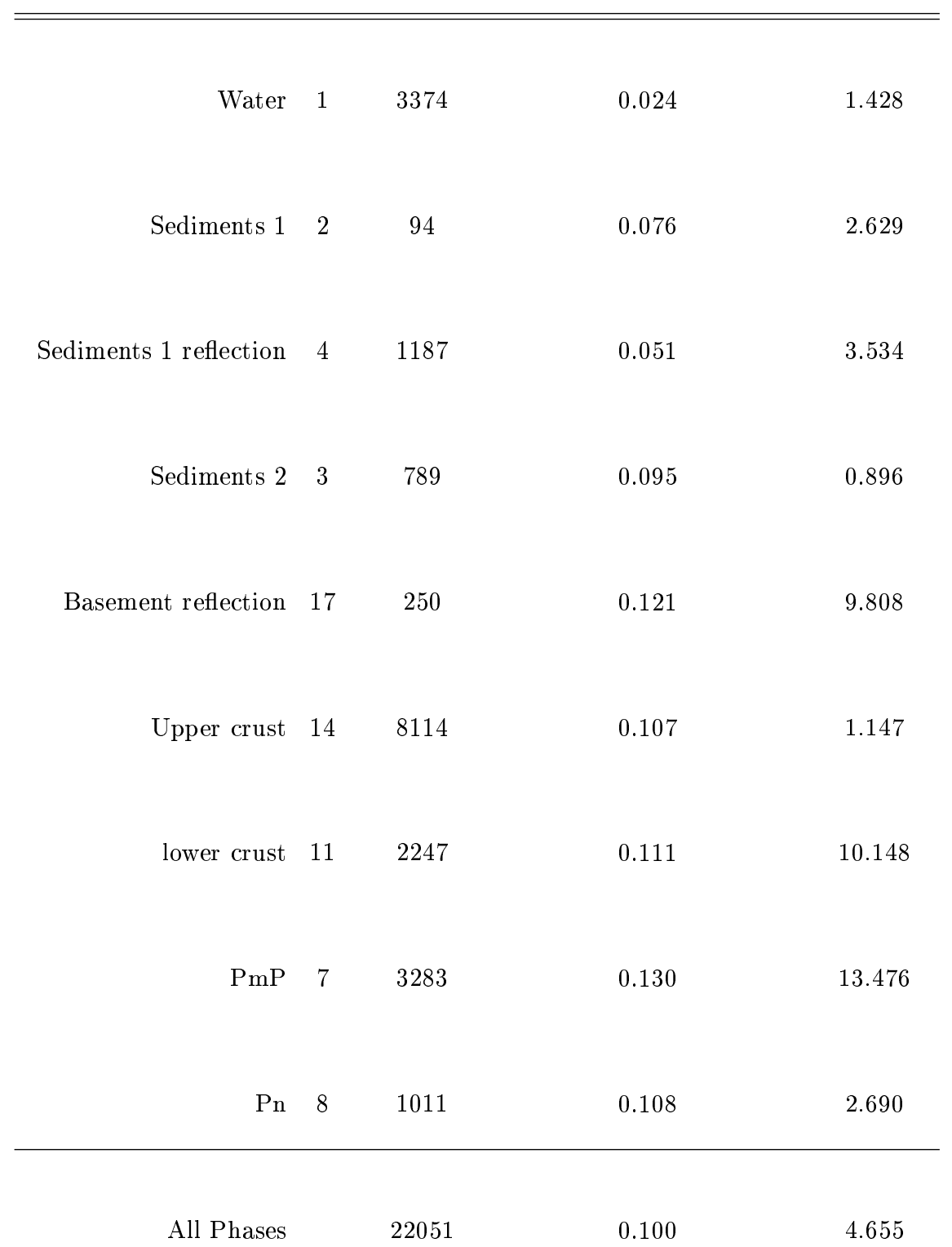

Table 2. Traveltime residuals and chi-squared error for all phases and the complete model of Profile S. 

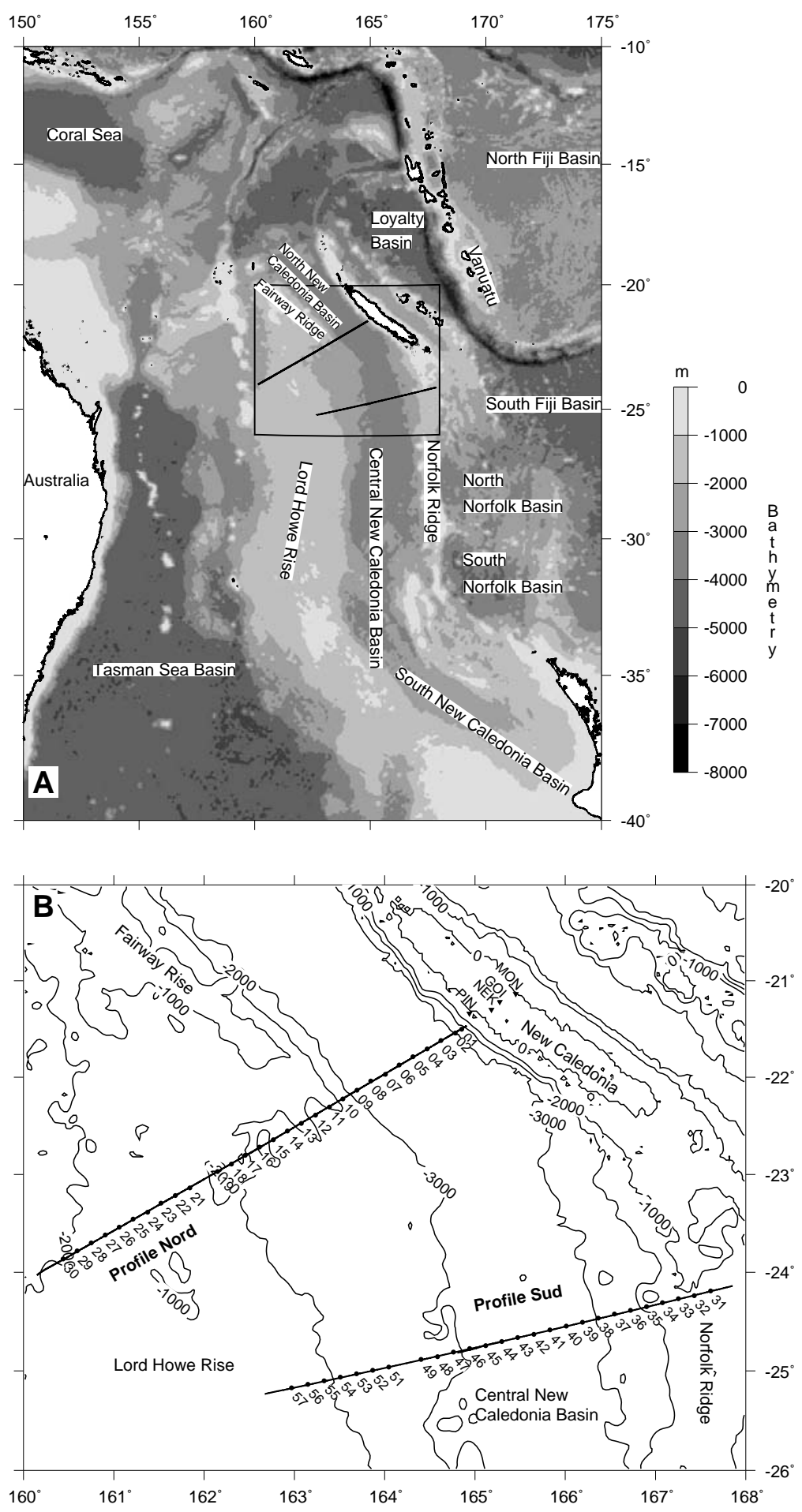

Figure 1. 


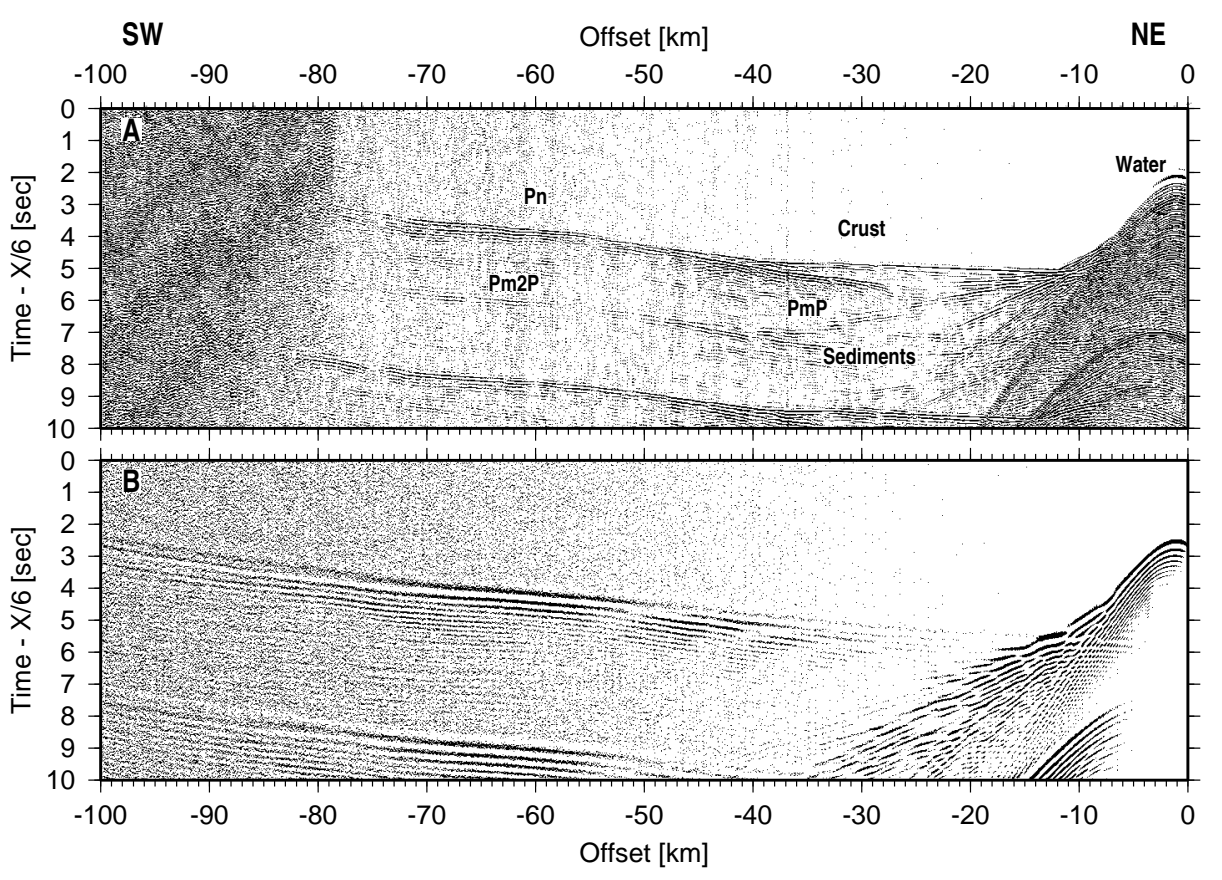

Figure 2. 


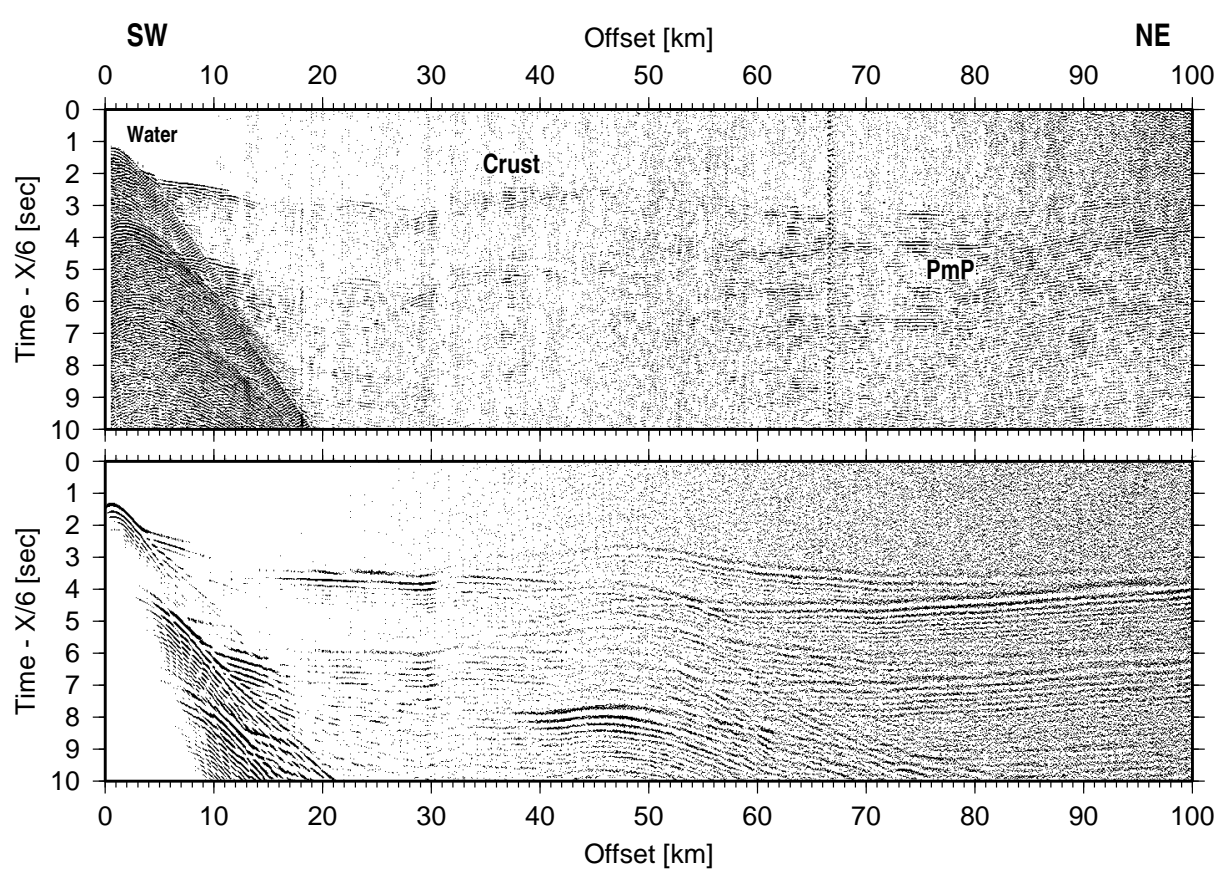

Figure 3. 


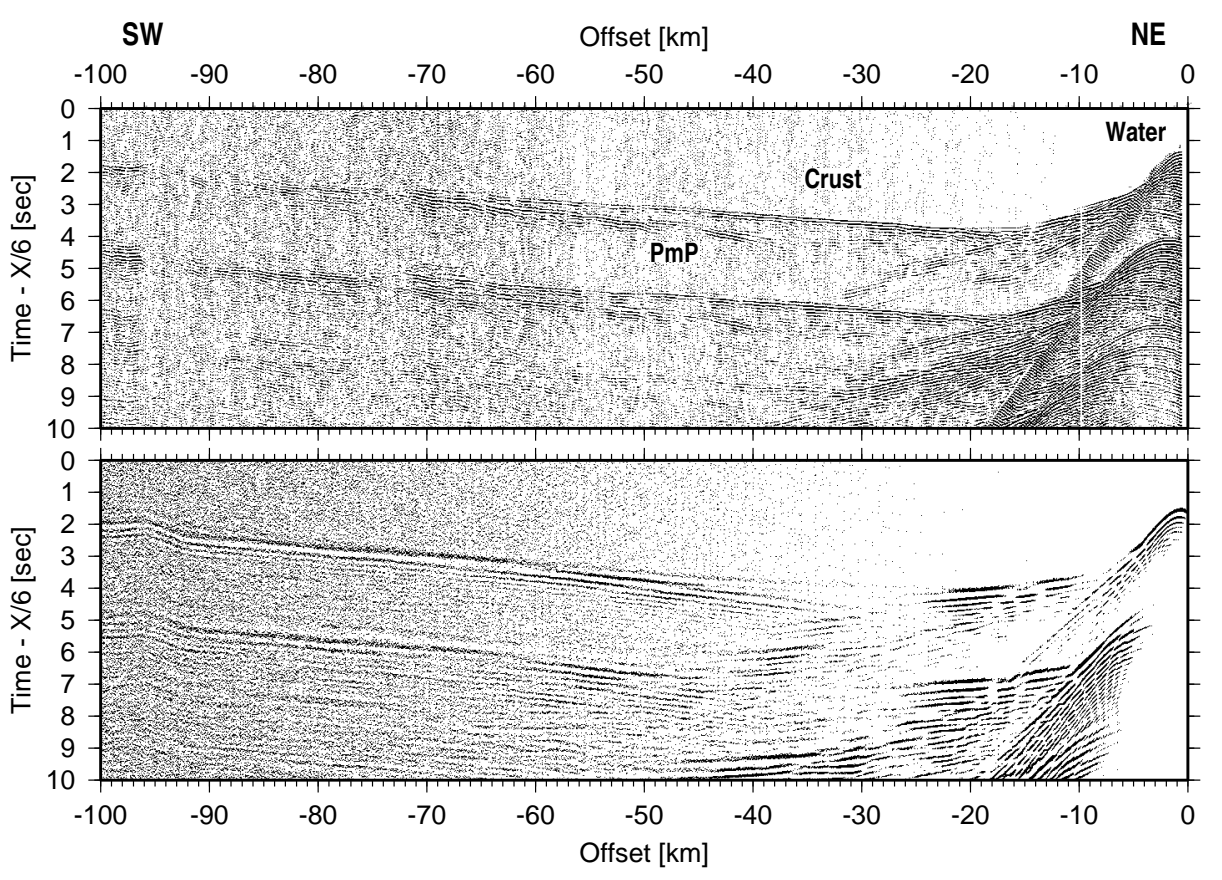

Figure 4. 


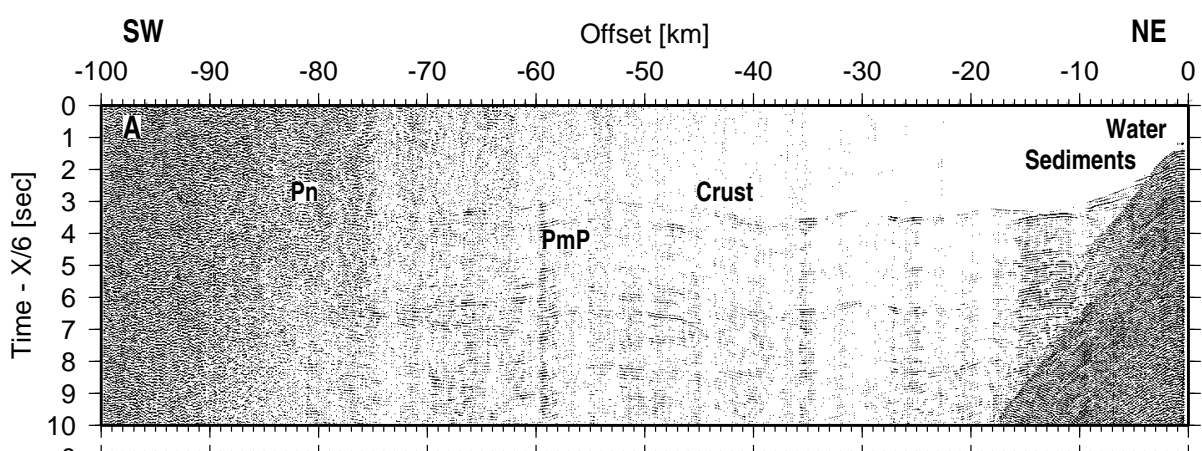

Figure 5.

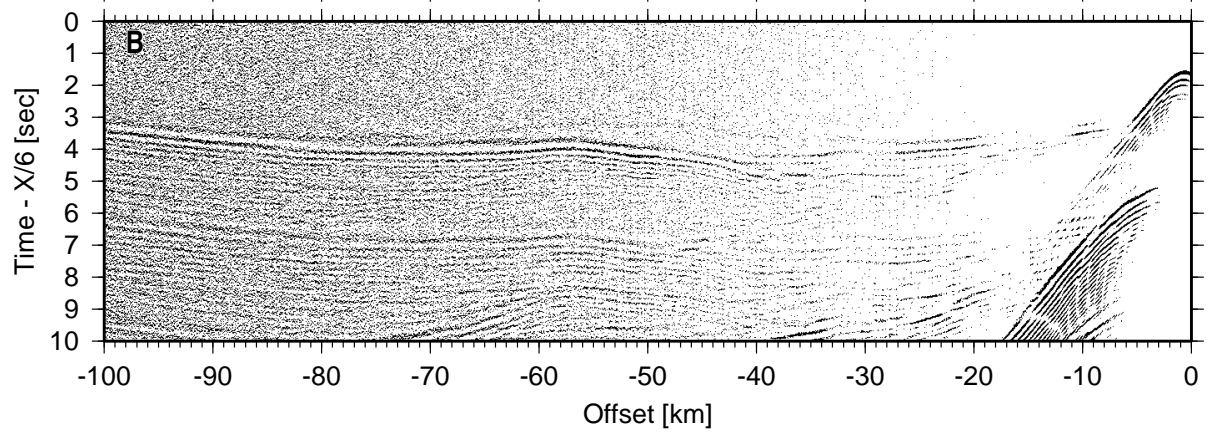



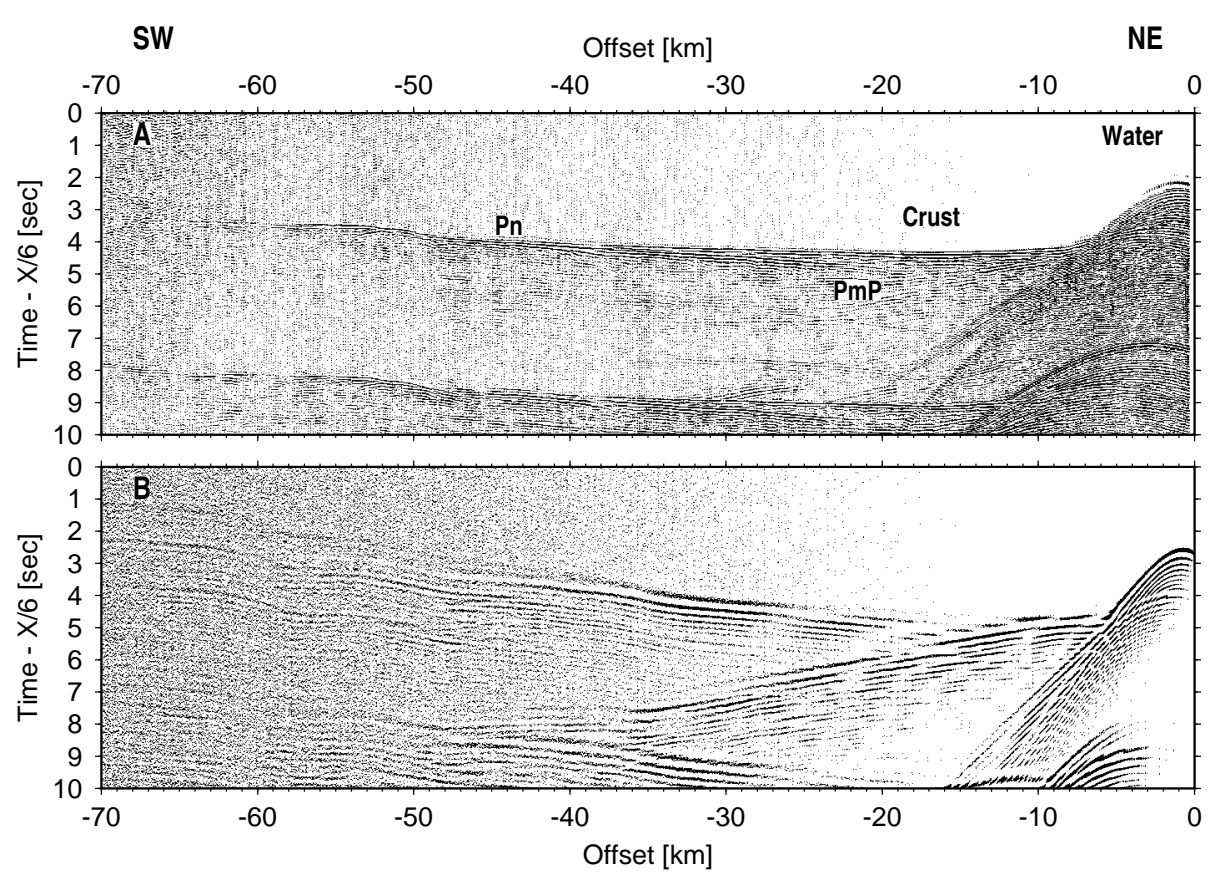

Figure 6. 


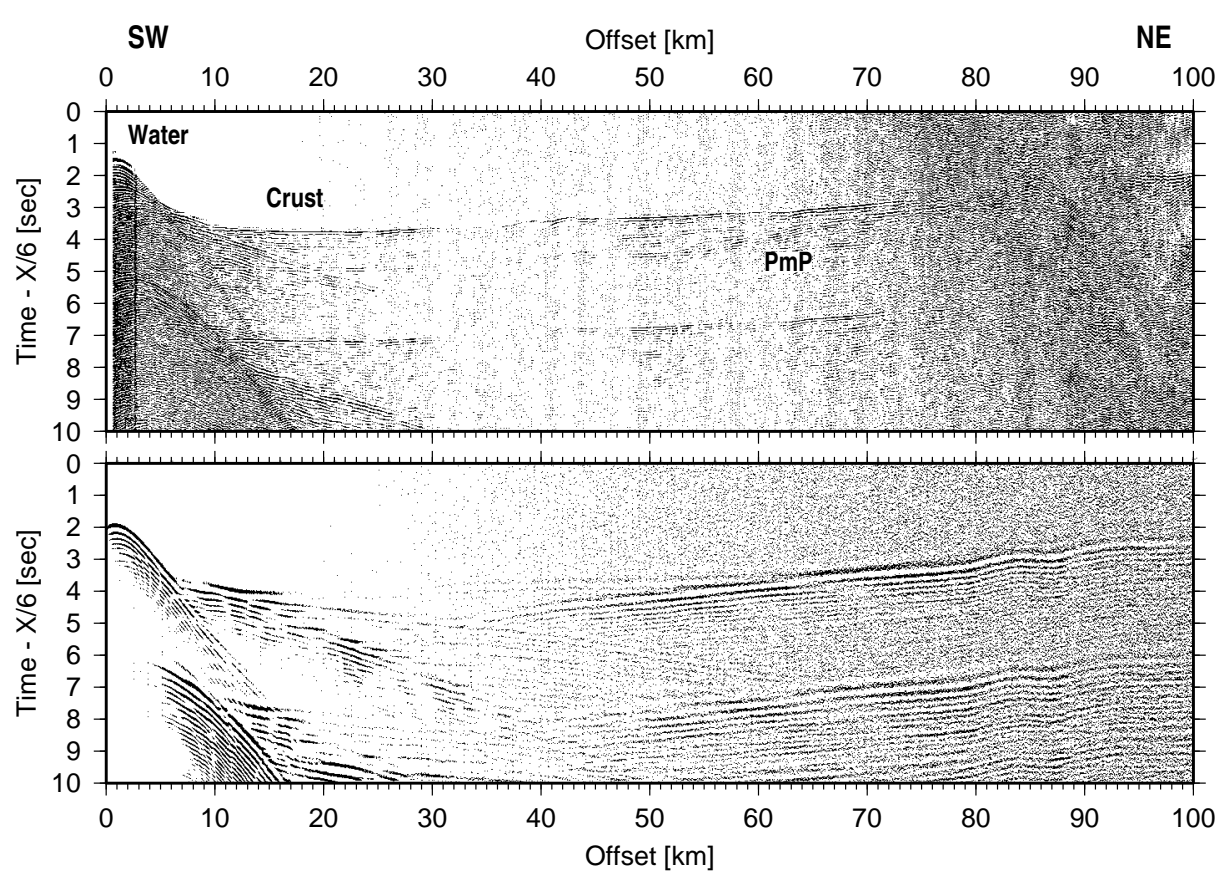

Figure 7. 


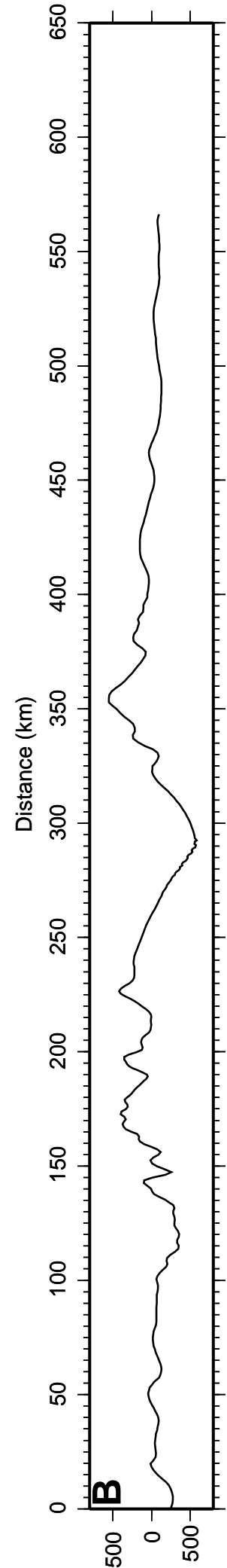

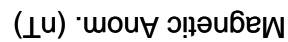

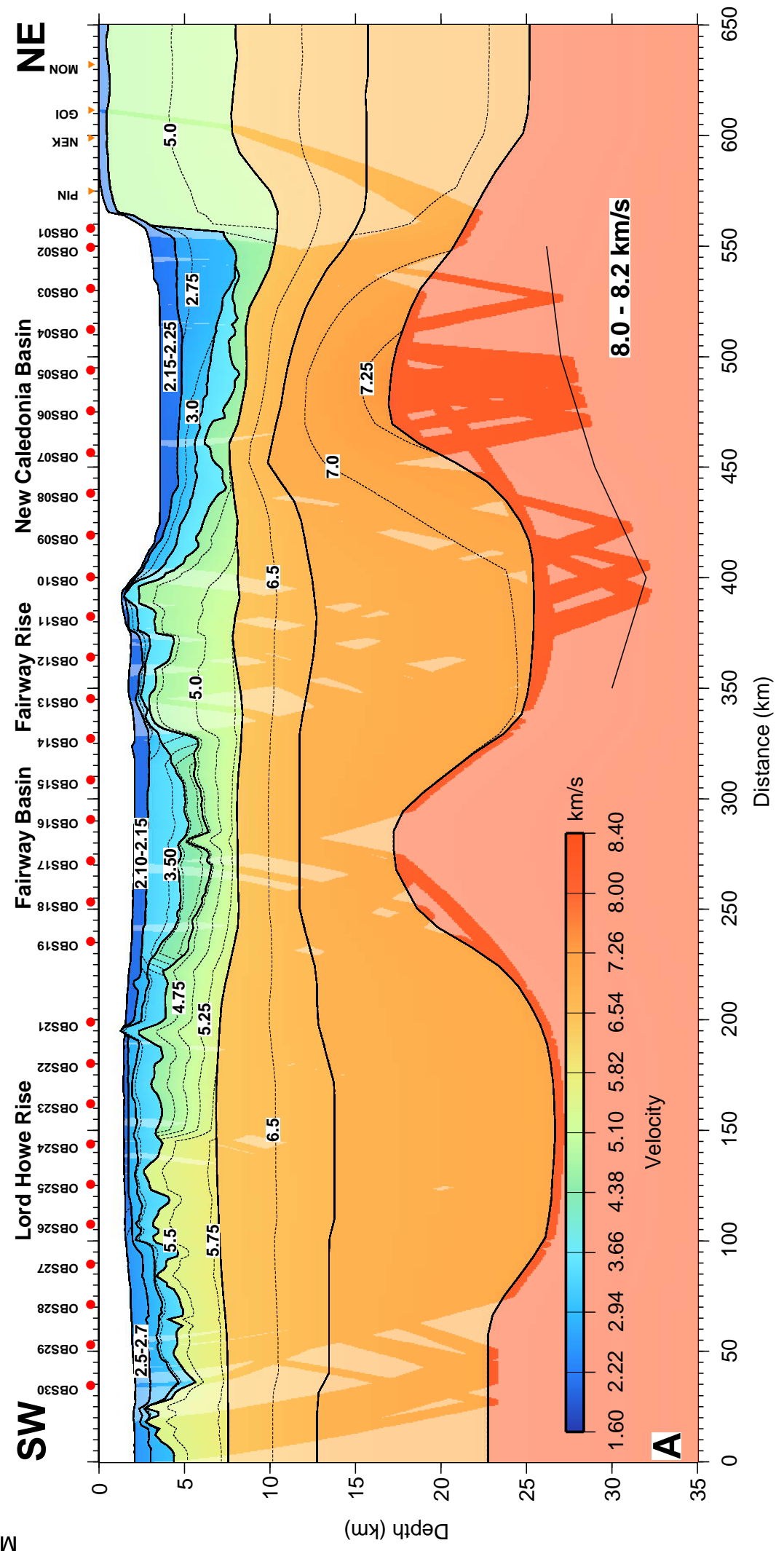

June 16, 2007, 1:41pm
D R A F T

Figure 8. 


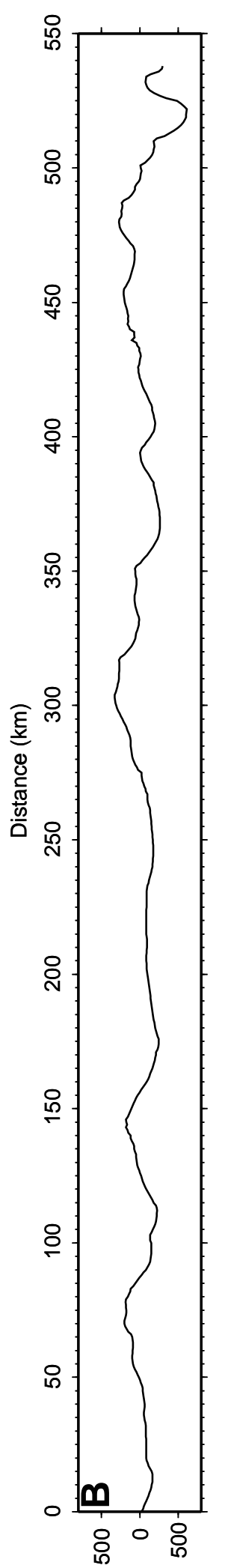

(ıu) $\cdot$ mou

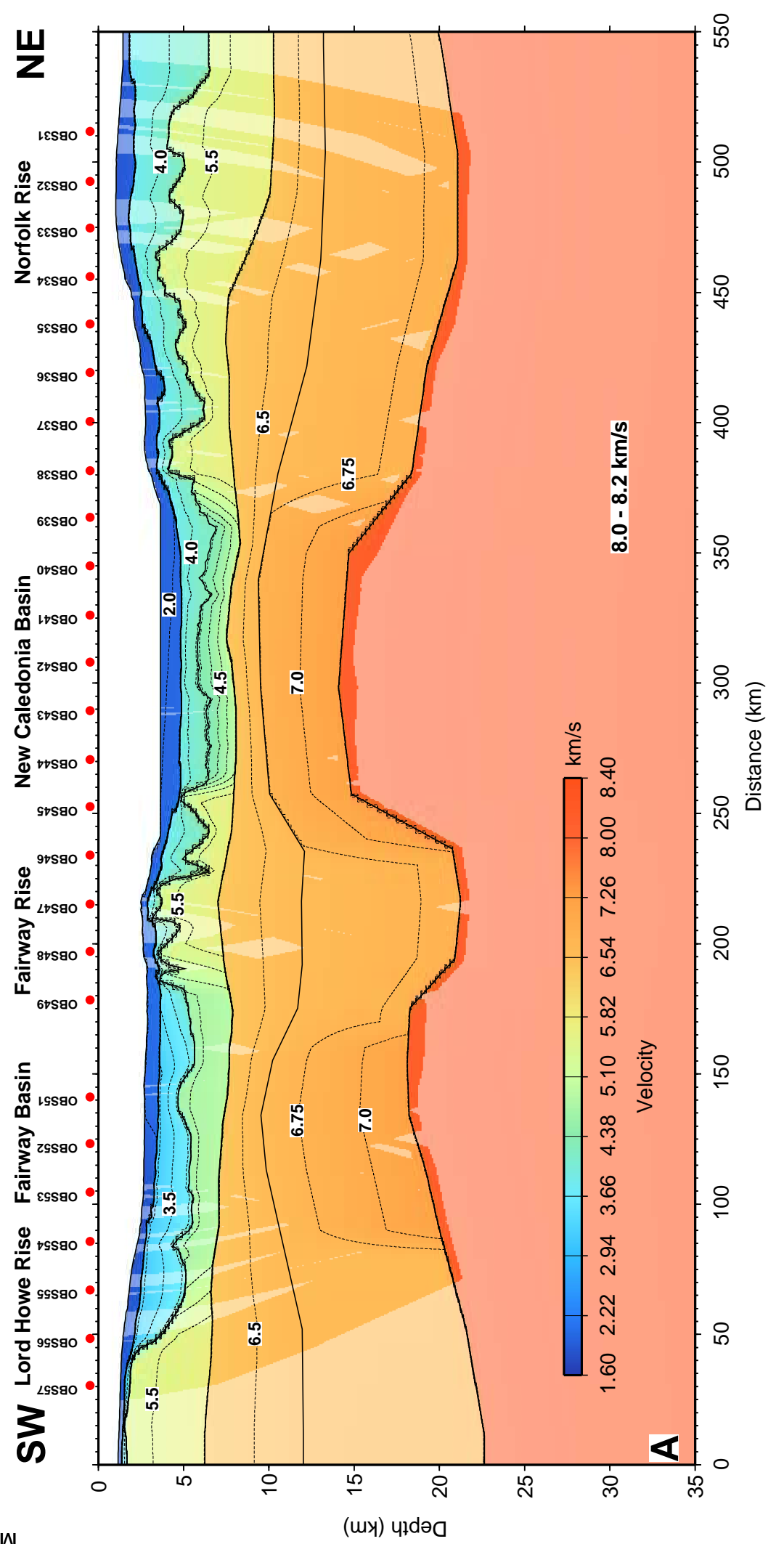

June 16, 2007, 1:41pm
D R A F T

Figure 9. 


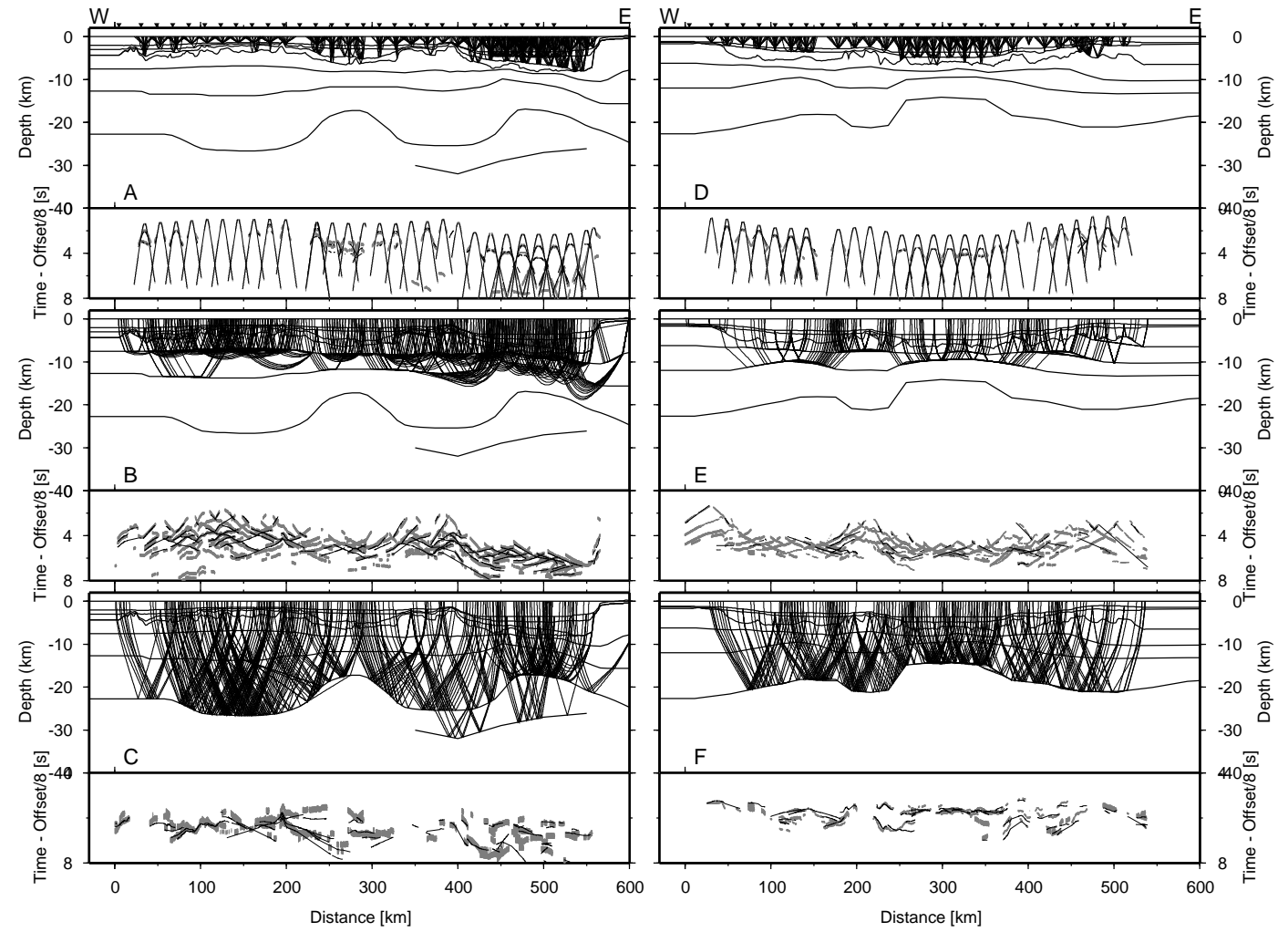

Figure 10. 

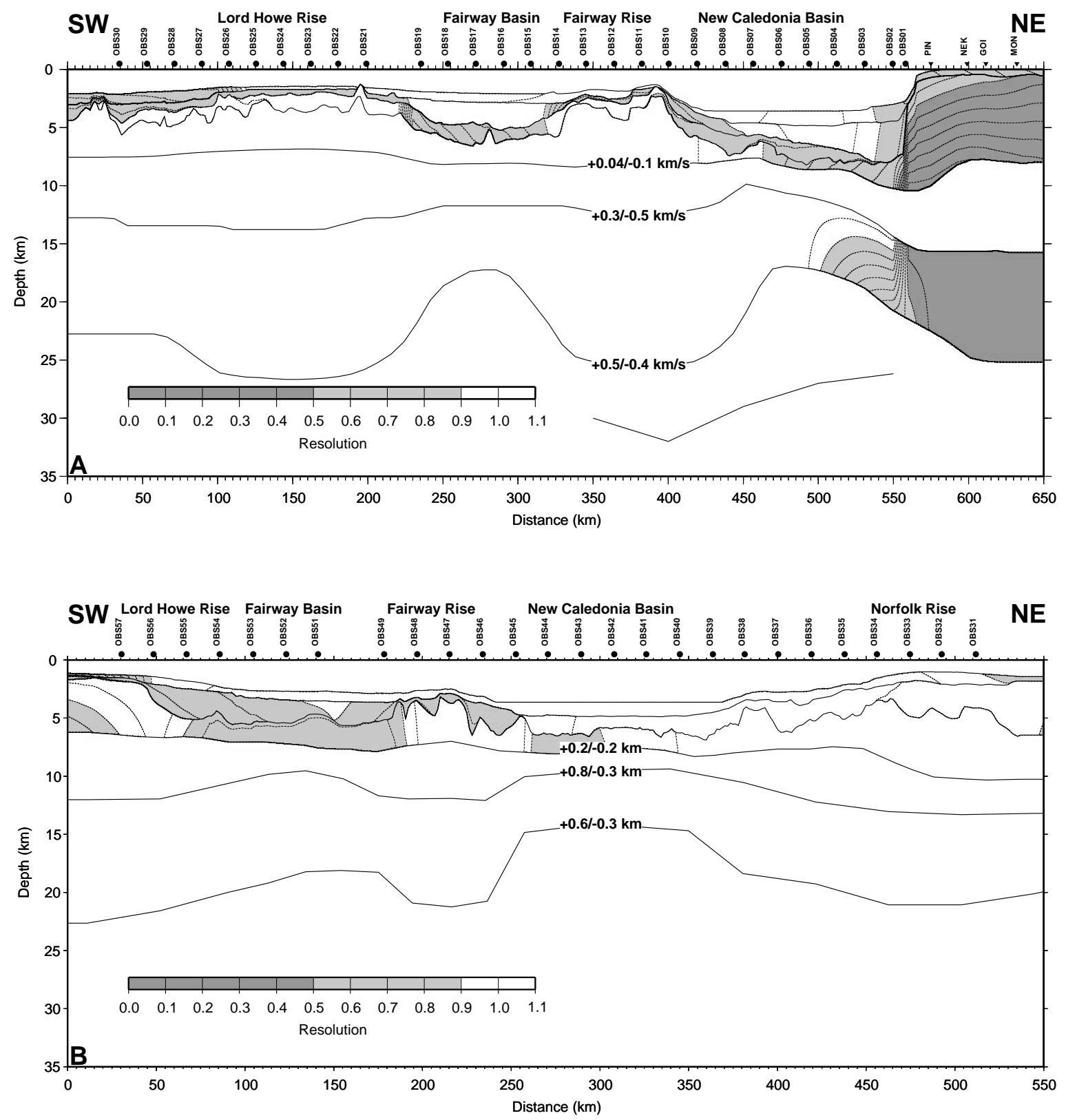

Figure 11. 


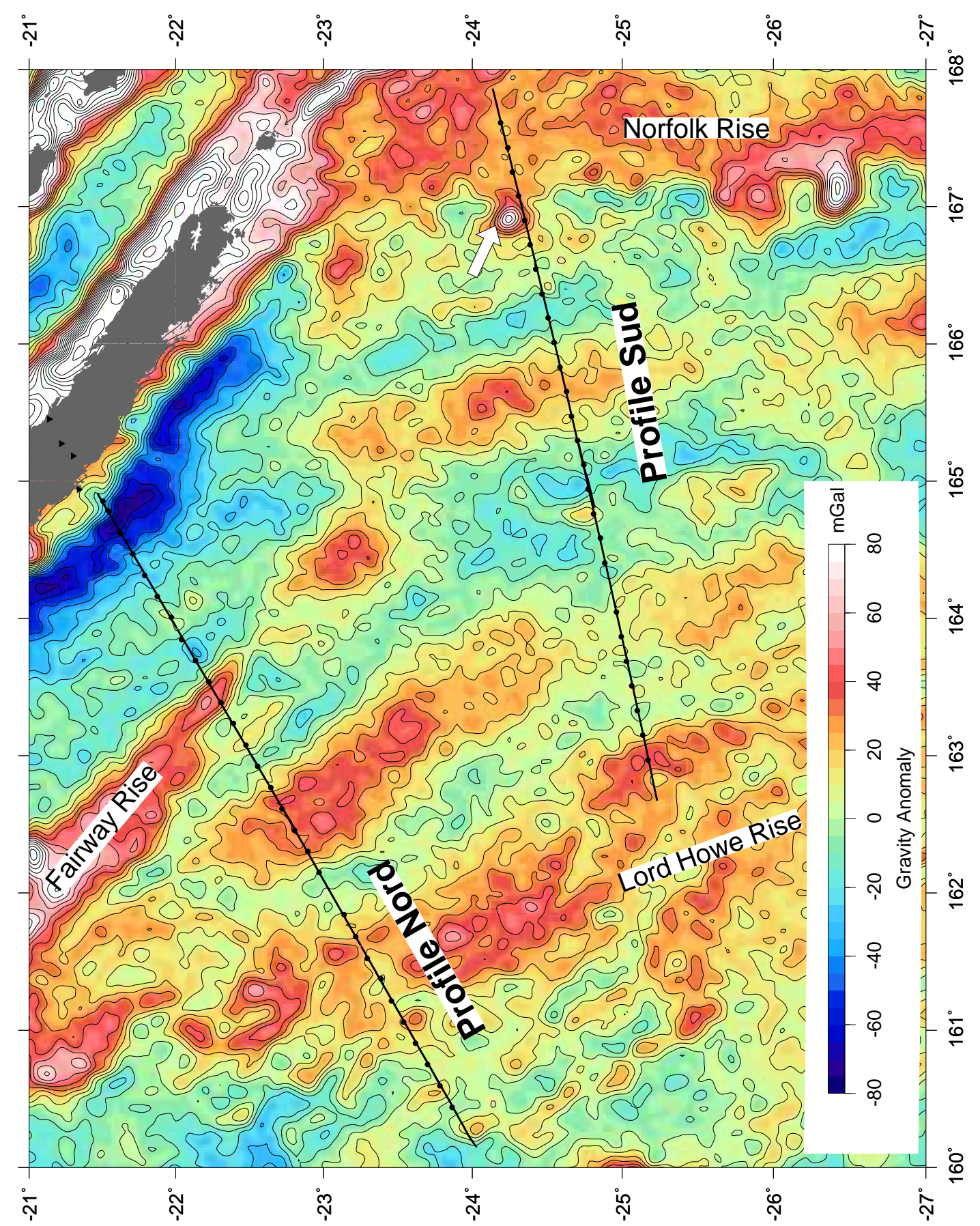

Figure 12. 

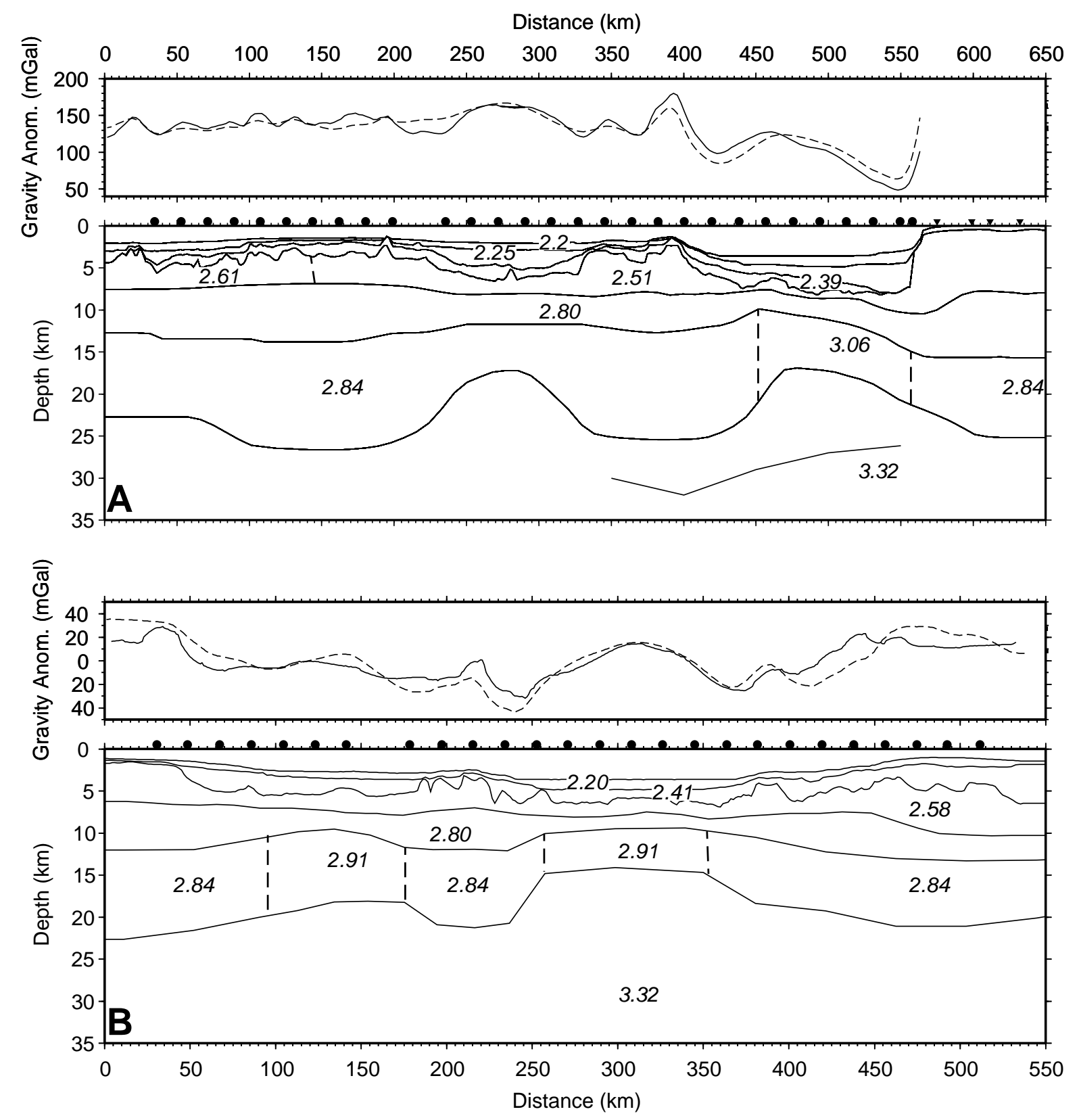

Figure 13.

D R A F T

June 16, 2007, 1:41pm

D R A F T 

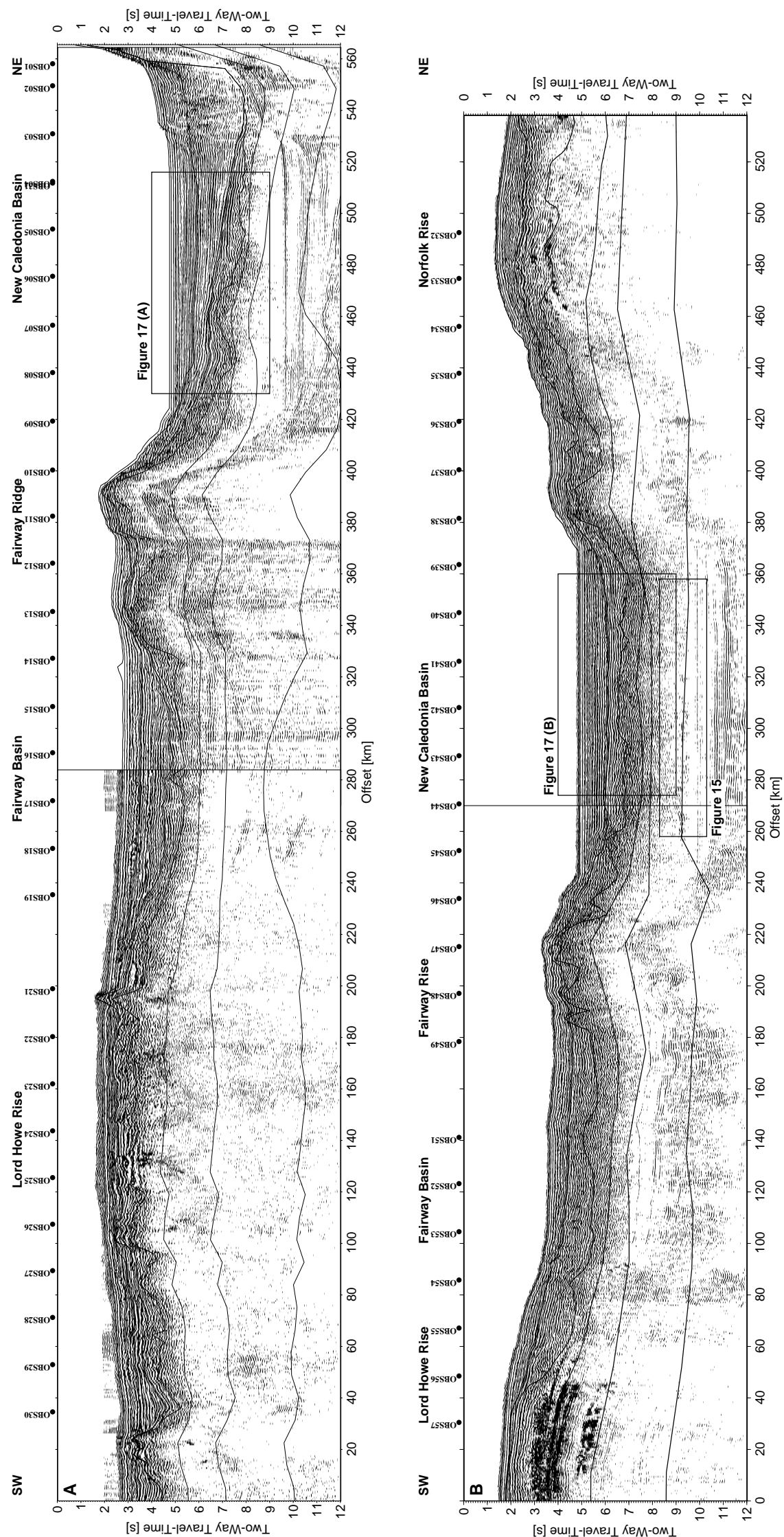

Figure 14.

D R A F T

June 16, 2007, 1:41pm

D R A F T 


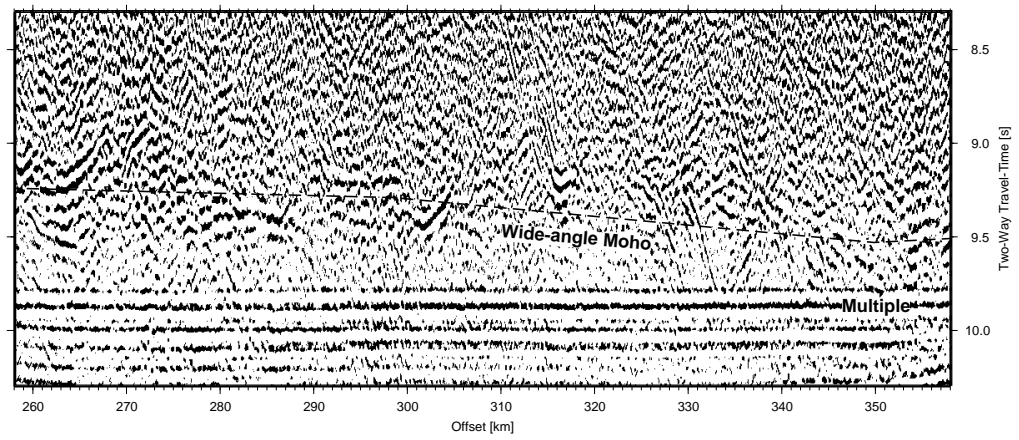

Figure 15. 

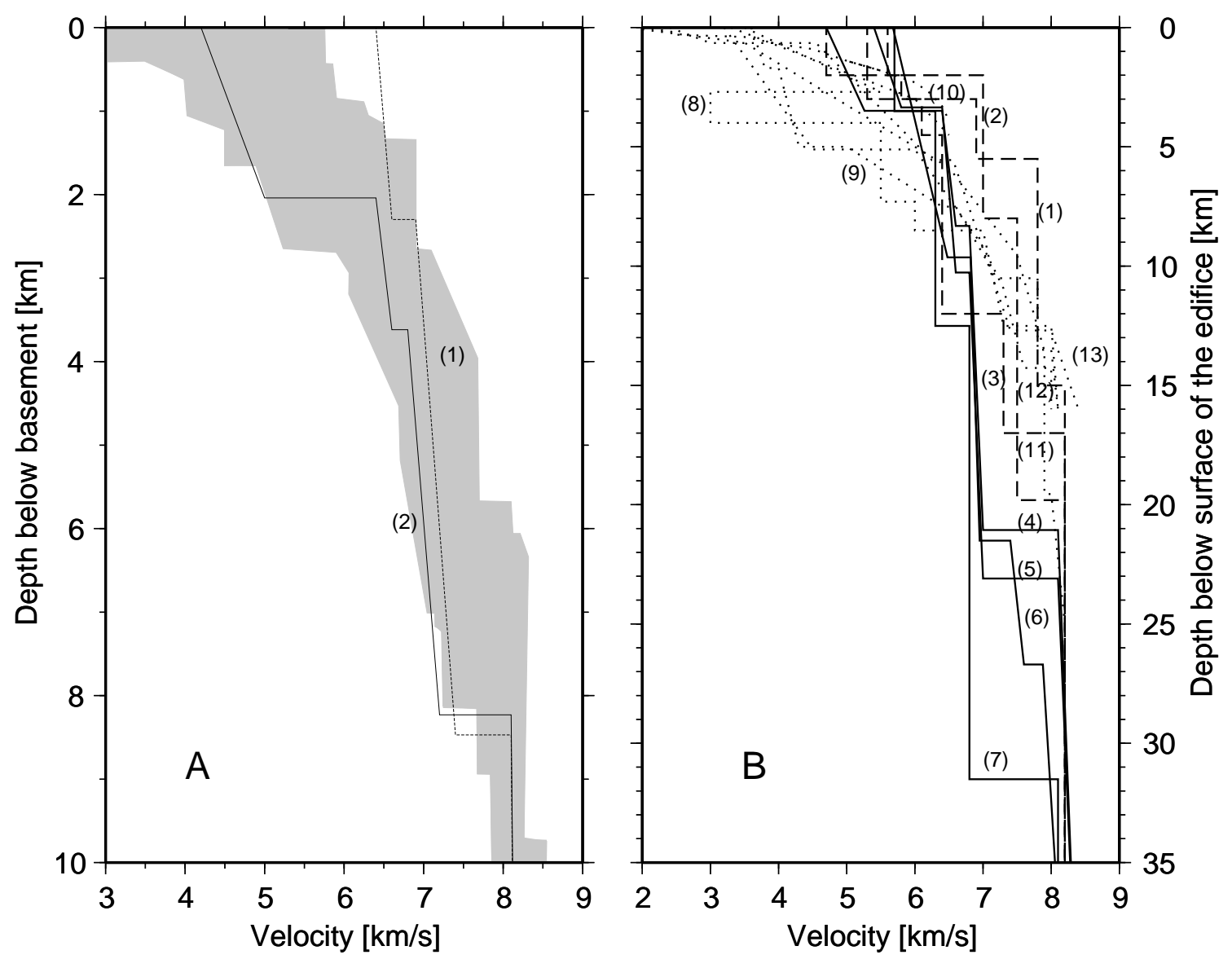

Figure 16. 

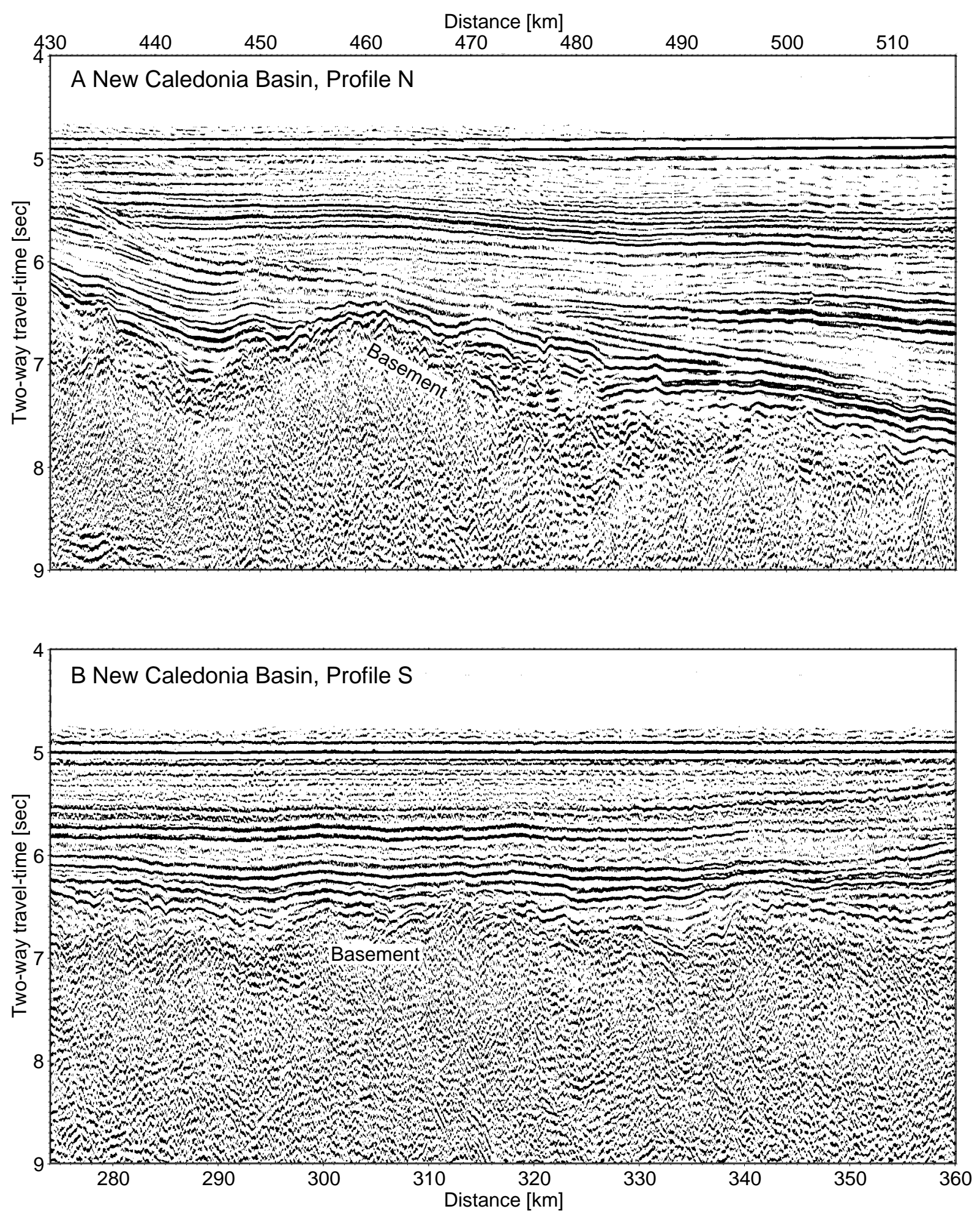

DFigiare 117.

June 16, 2007, 1:41pm

D R A F T 